\title{
Article
}

\section{The Potential of Digestate and the Liquid Fraction of Digestate as Chemical Fertiliser Substitutes under the RENURE Criteria}

\author{
Gregory Reuland ${ }^{1,2, *(\mathbb{D}}$, Ivona Sigurnjak ${ }^{1} \mathbb{D}$, Harmen Dekker ${ }^{2}$, Evi Michels ${ }^{1}$ and Erik Meers ${ }^{1}$ \\ 1 Department of Green Chemistry and Technology, Faculty of Bioscience Engineering, Ghent University, \\ Coupure Links 653, 9000 Gent, Belgium; ivona.sigurnjak@ugent.be (I.S.); evi.michels@ugent.be (E.M.); \\ erik.meers@ugent.be (E.M.) \\ 2 European Biogas Association, Rue d'Arlon 65, 1050 Brussels, Belgium; dekker@europeanbiogas.eu \\ * Correspondence: gregory.reuland@ugent.be
}

Citation: Reuland, G.; Sigurnjak, I.; Dekker, H.; Michels, E.; Meers, E. The Potential of Digestate and the Liquid Fraction of Digestate as Chemical Fertiliser Substitutes under the RENURE Criteria. Agronomy 2021, 11, 1374. https://doi.org/10.3390/ agronomy 11071374

Academic Editor: David Houben

Received: 31 May 2021

Accepted: 2 July 2021

Published: 7 July 2021

Publisher's Note: MDPI stays neutral with regard to jurisdictional claims in published maps and institutional affiliations.

Copyright: (C) 2021 by the authors. Licensee MDPI, Basel, Switzerland. This article is an open access article distributed under the terms and conditions of the Creative Commons Attribution (CC BY) license (https:// creativecommons.org/licenses/by/ $4.0 /)$.

\begin{abstract}
This study assessed how digestate and the liquid fraction (LF) of digestate would perform as candidate RENURE fertilisers (recovered nitrogen from manure) in nitrate vulnerable zones under the proposed criteria of the Joint Research Centre, namely, (i) a mineral nitrogen to total nitrogen ratio $\geq 90 \%\left(\mathrm{~N}_{\min }: \mathrm{TN} \geq 90 \%\right)$ or a total organic carbon to $\mathrm{TN}$ ratio $\leq 3$ (TOC:TN $\leq 3$ ); (ii) limits of $\leq 300$ copper $(\mathrm{Cu}) \mathrm{mg} \mathrm{kg}^{-1}$ and $\leq 800 \mathrm{Zinc}(\mathrm{Zn}) \mathrm{mg} \mathrm{kg}^{-1}$. These criteria were applied to unpublished data $(n=2622)$ on digestate compositional properties, further amended with data from the literature ( $n=180)$; digestate analysis from seven full-scale biogas facilities $(n=14)$; and biogas industry stakeholders $(\mathrm{n}=23)$. The results showed that $\mathrm{Cu}$ and $\mathrm{Zn}$ mostly met the criteria, with compliance rates of $94.7 \%$ (of 1035 entries) and $95.0 \%$ (of 1038 entries), respectively. Just above $5 \%$ (of 1856 entries) met the $\mathrm{N}_{\min } / \mathrm{TN} \geq 90 \%$ criterion, while $36 \%$ (of 1583 entries) met the TOC/TN $\leq 3$ criterion, while total compliance was $32 \%$ (of 1893 entries). When targeting the LF, total compliance increased noticeably, between 43 and 58\% depending on DM range, indicating that LFs are better suited RENURE candidate fertilisers than unseparated digestate.
\end{abstract}

Keywords: RENURE; digestate; manure; Nitrates Directive; SAFEMANURE; NUE; NFRV; liquid fraction; circular economy

\section{Introduction}

When poorly managed, livestock manure and slurries can lead to considerable amounts of methane $\left(\mathrm{CH}_{4}\right)$ and ammonia $\left(\mathrm{NH}_{3}\right)$, and to a lesser extent nitrous oxide $\left(\mathrm{N}_{2} \mathrm{O}\right)$, being emitted into the environment [1]; as well nutrient leaching, mainly of nitrogen $(\mathrm{N})$ and phosphorous (P) [2]. In the European Union (EU-28), it is estimated that the agricultural sector contributed almost $10 \%$ to total greenhouse gas (GHG) emissions in 2015, with manure management being responsible for $15 \%$ of the emissions within the agricultural sector [3]. As livestock husbandry in Europe follows a general trend towards intensification, as a corollary, considerable volumes of manure need to be processed safely to protect the environment ( $\mathrm{N}$ leaching) and human health. Moreover, increased area specialisation tends to further compound geographical imbalances of nutrients, with $\mathrm{N}$ surpluses overlapping areas traditionally associated with intensive livestock production [4,5]. Under the Nitrates Directive (ND) (91/676/EEC), the use of animal manure is limited to $170 \mathrm{~kg} \mathrm{~N} \mathrm{ha}^{-1} \mathrm{y}^{-1}$ in areas where the Nitrates Action Programme applies - the so-called nitrates vulnerable zones (NVZ), which cover about 61\% of European agricultural land [6] - to protect waters against pollution caused by nitrates $\left(\mathrm{NO}_{3}{ }^{-}\right)$from agricultural sources.

The 2030 Climate and Energy Framework includes EU-wide binding targets to cut GHG emissions by at least 40\% below 1990 levels and increase the share of renewable energy by at least $32 \%$ in the final consumption by 2030. In the frame of the European Green Deal, the longer-term ambition is to reach net-zero GHG emissions by 2050. Anaerobic digestion (AD) — which produces renewable power, heat, and fuel from organic waste-can 
be expected to play an important role in achieving the goals the EU has set for itself. The potential of biomethane in combination with carbon $(C)$ capture and storage to decarbonise the gas grid [7,8] and the transport sector [9] has been documented. However, AD could also play a crucial part in the sustainable management of organic waste streams such as manure by simultaneously providing renewable energy, closing nutrient loops, and reducing GHG emissions [10,11].

The adoption of the new Fertilising Products Regulation (FPR) ((EU) 2019/1009) opens the door to organic and waste-derived fertilisers under a unified European market. Nevertheless, the current limit of $170 \mathrm{~kg} \mathrm{~N} \mathrm{ha}^{-1} \mathrm{y}^{-1}$ in NVZ applies to any fertilising product that is partially or entirely derived from livestock manure. Consequently, this legally binding threshold is possibly hampering the use of certain bio-based fertilising materials, which, in some cases, bear little to no resemblance to the manure from which their nutrients were extracted, as they can contain high amounts of mineral $\mathrm{N}\left(\mathrm{N}_{\min }\right)$, effectively bringing them closer to chemical fertilisers and further away from raw manure in terms of plant nutrient uptake (Figure 1). As things stand currently, farmers tend to top up with energy-demanding chemical fertilisers as a result of the $170 \mathrm{~kg} \mathrm{~N} \mathrm{ha}^{-1} \mathrm{y}^{-1} \operatorname{limit}$ not meeting most crop requirements.

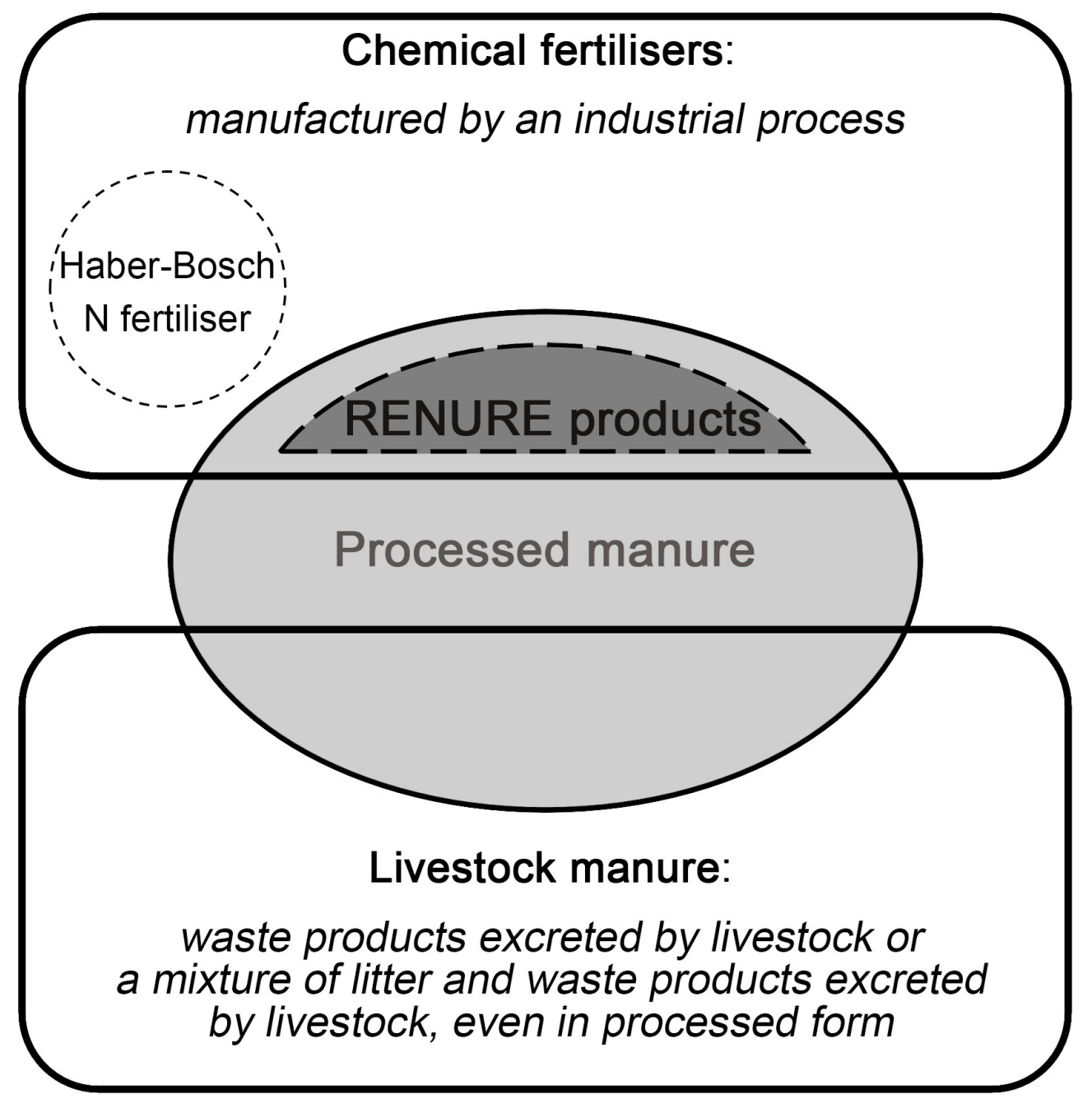

Figure 1. The diagram aims to clearly differentiate (i) unprocessed livestock manure; (ii) livestock manure that underwent some form of processing, but does not meet the RENURE requirements; (iii) chemical fertilisers; and (iv) RENURE-compliant "hybrids" derived from animal manure. Adapted from the RENURE study [12]. 
To lift barriers for such manure-derived products, the European Commission (EC) set up the SAFEMANURE study group to develop criteria for the safe use of processed manure materials in NVZ above the limits established in the ND (91/676/EEC). Such materials are known under the acronym 'RENURE' for "recovered nitrogen from manure", and are defined as "any nitrogen containing substance fully or partially derived from livestock manure through processing that can be used in areas with water pollution by nitrogen following otherwise identical provisions applied to nitrogen containing chemical fertilisers as defined in the Nitrates Directive (91/676/EEC), while ensuring the achievement of the Nitrates Directive's objective and providing adequate agronomic benefits to enhance plant growth" [12] (Figure 1).

In alignment with the ND's main goal to protect waterbodies against $\mathrm{NO}_{3}{ }^{-}$pollution, the primary objective of the RENURE study was to assess the agronomic performance of candidate fertilisers, defined by their leaching potential and nutrient assimilation capacity by plants or nitrogen use efficiency (NUE), which can be defined as the fraction of total $\mathrm{N}$ (TN) applied (imported N) absorbed by the plant (exported N). To this end, the nitrogen fertiliser replacement value (NFRV) - defined as the amount of $\mathrm{N}_{\text {min }}$ fertiliser saved by using organic $\mathrm{N}$ materials while reaching the same crop yield [13] — of candidate RENURE products was determined by comparing their NUE against that of a chemical N HaberBosch fertiliser. Digestate is featured on the list of potential RENURE materials, albeit as a medium priority product, and has been gaining attention in recent years as a possible substitute to chemical fertilisers [14]. Pooled data compilations in the literature highlight the broad compositional ranges that can be expected from digestate. Dry matter (DM) content from various feedstocks was found to range anywhere between 15 and $457 \mathrm{~g} \mathrm{~kg}^{-1}$ FM; organic matter (OM) between 386 and $770 \mathrm{~g} \mathrm{~kg}^{-1} \mathrm{DM}$; total carbon (TC) and total organic carbon (TOC) between 360 and 450 and 273 and $374 \mathrm{~g} \mathrm{~kg}^{-1} \mathrm{DM}$, respectively; the $\mathrm{C} / \mathrm{N}$ ratio from 2.0 to 24.8 ; $\mathrm{TN}$ as low as 1.2 up to $15 \mathrm{~g} \mathrm{~kg}^{-1} \mathrm{FM}$; ammonium nitrogen $\left(\mathrm{NH}_{4}-\mathrm{N}\right)$ from 1.5 to $6.8 \mathrm{~g} \mathrm{~kg}^{-1} \mathrm{FM}$; and $\mathrm{pH}$ from 7.3 to 9.0 [15-18].

Further treatment of digestate can help improve its environmental and agronomic predictability, while also allowing for lowered transport costs. One such way is mechanical separation (e.g., sedimentation, belt press, screw press, centrifugation), which reshuffles the nutrients into an $\mathrm{N}$ - and potassium-rich (K) liquid fraction (LF) and a P-rich solid fraction (SF) $[15,19]$. The dewatered SF can then more easily be transported while the LF can be applied as fertiliser or undergo further nutrient refinery and solids' removal [20]. Owing to their higher NUE and the incumbent lower risk of N leaching, chemical fertilisers obtained via the Haber-Bosch process were used as a benchmark to assess the suitability of candidate RENURE products. Accordingly, those that perform similarly to chemical fertilisers are proposed to be exempted from the thresholds currently in vigour for fertilising materials partially or entirely derived from livestock manure in NVZ (Figure 1). To assess the agronomic performance of RENURE materials, two key indicators have been put forward: (i) a mineral $\mathrm{N}$ to total $\mathrm{N}$ ratio equal or superior to $90 \%\left(\mathrm{~N}_{\min } / \mathrm{TN} \geq 90 \%\right)$ or (ii) a total organic $\mathrm{C}$ to total $\mathrm{N}$ ratio equal or inferior to 3 (TOC/TN $\leq 3)$. Where a higher TOC/TN ratio indicates a more organic-like material, there is a higher likelihood of the $\mathrm{N}$ it contains being embedded in the organic matrix, which in turn is positively correlated with the risk of $\mathrm{N}$ leaching and negatively correlated with NUE, whereas the opposite holds true for $\mathrm{N}_{\min } / \mathrm{TN}$.

This study aims to assess how digestate and the LF of digestate would perform when set against these RENURE limits. In this comparison, it is anticipated that the LF of digestate better matches these criteria than unseparated digestate. Therefore, a mechanical separation could constitute the lowest prerequisite to benefit from the RENURE status, thus phasing out the use of unseparated digestate in NVZ. Additionally, we assessed the performance of digestate against the heavy metals (HMs) limits that all RENURE fertilisers would have to comply with: (i) $300 \mathrm{mg} \mathrm{kg}^{-1} \mathrm{DM}$ for copper (Cu) and (ii) $800 \mathrm{mg} \mathrm{kg}^{-1} \mathrm{DM}$ for Zinc $(\mathrm{Zn})$. To this end, unpublished data $(\mathrm{n}=2622)$ on compositional characteristics of digestate, provided by the European Biogas Association (EBA), were collected from national biogas associations in five countries (Austria, Germany, Finland, France, and United Kingdom) 
(Section 2.1.1). A separate digestate database was also created (Section 2.1.2). These two databases were screened and subsequently merged into a single database (Section 2.1) that was set against the RENURE criteria specified above.

\section{Materials and Methods}

\subsection{Digestate Databases}

The databases that were used for this study are detailed in the ensuing sections. For overall clarity and to better differentiate them throughout the remainder of this study, we shall refer to (i) "database A" (Table 1) as described in Section 2.1.1 and (ii) "database B" (Table 1) as described in Section 2.1.2. Databases A and B were subsequently merged together to form "database $C$ ", the solidified and final database used in this study (Section 3.3). In all subsequent tables, the mean and median values are based on the available number of datapoints for each considered parameter.

Table 1. Average compositional properties of digestate. Left: database A, datapoints obtained from the European Biogas Association (excluding outliers). Right: database B, datapoints compiled from (i) the literature review; (ii) the sampling campaign; and (iii) data collection from industrial stakeholders. Here, $\mathrm{DM}=$ dry matter; $\mathrm{FM}=$ fresh matter; $\mathrm{OM}=$ organic matter; $\mathrm{TN}=$ total nitrogen; $\mathrm{NH}_{4}-\mathrm{N}=$ ammonium nitrogen $\left(\mathrm{N}_{\min }\right) ; \mathrm{K}_{2} \mathrm{O}=$ potassium oxide; $\mathrm{P}_{2} \mathrm{O}_{5}=$ phosphorus pentoxide; $\mathrm{Zn}=$ zinc; $\mathrm{Cu}=$ copper; $\mathrm{Hg}=$ mercury; $\mathrm{n}=$ digestate sample size.

\begin{tabular}{|c|c|c|c|c|c|c|c|}
\hline \multirow[b]{2}{*}{ Parameter } & \multirow[b]{2}{*}{ Unit } & \multicolumn{3}{|c|}{ (Left) Database A } & \multicolumn{3}{|c|}{ (Right) Database B } \\
\hline & & Mean \pm Stdev & Median & $\mathbf{n}$ & Mean \pm Stdev & Median & $\mathbf{n}$ \\
\hline $\mathrm{pH}$ & - & $7.9 \pm 0.3$ & 7.9 & 1808 & $8.2 \pm 0.4$ & 8.2 & 119 \\
\hline $\mathrm{DM}$ & $\mathrm{g} \mathrm{kg}^{-1} \mathrm{FM}$ & $57 \pm 26$ & 53 & 2100 & $56 \pm 28$ & 52 & 184 \\
\hline $\mathrm{OM}$ & $\mathrm{g} \mathrm{kg}^{-1} \mathrm{DM}$ & $699 \pm 106$ & 707 & 1831 & $652 \pm 94$ & 676 & 77 \\
\hline TOC & $\mathrm{g} \mathrm{kg}^{-1} \mathrm{DM}$ & $388 \pm 59$ & 393 & 1831 & $340 \pm 75$ & 352 & 86 \\
\hline $\mathrm{TN}$ & $\mathrm{g} \mathrm{kg}^{-1} \mathrm{DM}$ & $102 \pm 53$ & 89 & 1758 & $88 \pm 49$ & 79 & 178 \\
\hline $\mathrm{N}_{\min }\left(\mathrm{NH}_{4}-\mathrm{N}\right)$ & $\mathrm{g} \mathrm{kg}^{-1} \mathrm{DM}$ & $60 \pm 43$ & 46 & 1945 & $59 \pm 40$ & 46 & 166 \\
\hline $\mathrm{K}_{2} \mathrm{O}$ & $\mathrm{g} \mathrm{kg}^{-1} \mathrm{DM}$ & $55 \pm 29$ & 52 & 1447 & $60 \pm 35$ & 55 & 71 \\
\hline $\mathrm{P}_{2} \mathrm{O}_{5}$ & $\mathrm{~g} \mathrm{~kg}^{-1} \mathrm{DM}$ & $35 \pm 17$ & 33 & 1452 & $40 \pm 28$ & 31 & 126 \\
\hline $\mathrm{Zn}$ & $\mathrm{mg} \mathrm{kg}{ }^{-1} \mathrm{DM}$ & $347 \pm 239$ & 299 & 1019 & $751 \pm 848$ & 425 & 37 \\
\hline $\mathrm{Cu}$ & $\mathrm{mg} \mathrm{kg}^{-1} \mathrm{DM}$ & $97 \pm 108$ & 70 & 1020 & $233 \pm 368$ & 103 & 39 \\
\hline $\mathrm{Hg}$ & $\mathrm{mg} \mathrm{kg}^{-1} \mathrm{DM}$ & $11 \times 10^{-2} \pm 13 \times 10^{-2}$ & $7 \times 10^{-2}$ & 994 & $15 \times 10^{-2} \pm 38 \times 10^{-2}$ & $5 \times 10^{-2}$ & 11 \\
\hline $\mathrm{N}_{\min } / \mathrm{TN}$ & $\%$ & $58 \pm 18$ & 57 & 1729 & $61 \pm 14$ & 62 & 160 \\
\hline $\mathrm{TOC} / \mathrm{TN}$ & - & $4.8 \pm 2.8$ & 3.9 & 1518 & $6.5 \pm 9.1$ & 4 & 86 \\
\hline
\end{tabular}

\subsubsection{Database A}

A digestate registry containing 2622 entries of compositional data on macro- and microelements, $\mathrm{pH}, \mathrm{OM}, \mathrm{DM}, \mathrm{HM}$, viable weed seeds, and common pathogens was used as starting point for this study. A preliminary screening of the dataset was performed to keep only the datapoints linked to feedstocks that used a combination of animal manure co-digested with biowaste and/or crops, which would make them suitable candidate RENURE materials. A univariate analysis was then carried out to discard unrealistic and potential outliers for each parameter using SPSS Statistics 27 (IBM Corp: Armonk, NY, USA). A multiplication factor of 1.5 of the interquartile range was used to earmark the lower and upper bounds for potential outliers. Following recommendations of our statistical department, the potential outliers were then compared to data from database $B$ (as described in the following section) - obtained from the literature review, the digestate sampling and analysis campaign, and confidential data collected from the biogas industryto determine whether they would be discarded or kept. As large as the database was, it did not contain any information on whether a separation technology (sedimentation, belt press, screw press, centrifugation) might have been used. Therefore, digestate entries had to be considered as containing unseparated and LFs of digestate based on their DM content. Two methods were employed to target the LF in database A (discussed in Section 4.7): (i) using DM ranges associated with LF referenced in literature; (ii) using the DM ranges 
of the positively identified LF cases from database B (Section 4.6). The main results from database A are presented in Table 1.

\subsubsection{Database B}

Database A was further amended with digestate compositional characteristics collected from three additional sources (described in the following subsections): (i) a review of existing literature, (ii) experimental characterisation of fresh digestate samples, and (iii) data collection from industrial biogas stakeholders. The compiled data from these three sources, referred to as database $B$, can be found in Table 1 (average values from the three individual data sources can be found under Tables A1-A3 of Appendix A). Database B was screened for extreme outliers, defined as three times the value of the interquartile range below the first quartile or above the third quartile. Database B was then used as a reference against which database A was compared. In this way, the lowest and highest values for each parameter found in database $B$ were used to adjust the ranges from database $A$ in a pairwise comparison, thus correcting, when necessary, the values that had erroneously been identified as outliers via the initial statistical screening. Once database A was processed this way, the two datasets (A and B) were combined to form the final database C (Table 2), against which the RENURE criteria were assessed. The main results of the three combined sets of data used for database B are shown in Table 1.

Table 2. Left: database $C$, the final digestate compositional ranges resulting from the screening and subsequent merging of databases A and B. Right: compositional range of the digestate entries from database $C$ that complied with $\mathrm{N}_{\min } / \mathrm{TN} \geq 90 \%$ or $\mathrm{TOC} / \mathrm{TN} \leq 3$. Here, $\mathrm{DM}=$ dry matter; $\mathrm{FM}=$ fresh matter; $\mathrm{OM}=$ organic matter; $\mathrm{TN}=$ total nitrogen; $\mathrm{NH}_{4}-\mathrm{N}=$ ammonium nitrogen $\left(\mathrm{N}_{\text {min }}\right) ; \mathrm{K}_{2} \mathrm{O}=$ potassium oxide; $\mathrm{P}_{2} \mathrm{O}_{5}=$ phosphorus pentoxide; $\mathrm{Zn}=$ zinc; $\mathrm{Cu}=$ copper; $\mathrm{Hg}=$ mercury; $\mathrm{n}=$ digestate sample size.

\begin{tabular}{|c|c|c|c|c|c|c|c|}
\hline \multirow[b]{2}{*}{ Parameter } & \multirow[b]{2}{*}{ Unit } & \multicolumn{3}{|c|}{ (Left) Database C } & \multicolumn{3}{|c|}{$\begin{array}{l}\text { (Right) Database C: Compliance with } \\
\text { TOC/TN } \leq 3 \text { or } N_{\min } / T N \geq 90 \%\end{array}$} \\
\hline & & Mean \pm Stdev & Median & $\mathbf{n}$ & Mean \pm Stdev & Median & $\mathbf{n}$ \\
\hline $\mathrm{pH}$ & - & $8.0 \pm 0.3$ & 8 & 1905 & $8.0 \pm 0.3$ & 8.1 & 519 \\
\hline DM & $\mathrm{g} \mathrm{kg}^{-1} \mathrm{FM}$ & $57 \pm 26$ & 53 & 2265 & $38 \pm 14$ & 35 & 606 \\
\hline $\mathrm{OM}$ & $\mathrm{g} \mathrm{kg}^{-1} \mathrm{DM}$ & $697 \pm 106$ & 705 & 1887 & $612 \pm 86$ & 621 & 575 \\
\hline TOC & $\mathrm{g} \mathrm{kg}^{-1} \mathrm{DM}$ & $386 \pm 61$ & 391 & 1896 & $338 \pm 51$ & 342 & 587 \\
\hline $\mathrm{TN}$ & $\mathrm{g} \mathrm{kg}^{-1} \mathrm{DM}$ & $100 \pm 53$ & 87 & 1913 & $158 \pm 45$ & 151 & 606 \\
\hline $\mathrm{N}_{\min }\left(\mathrm{NH}_{4}-\mathrm{N}\right)$ & $\mathrm{g} \mathrm{kg}^{-1} \mathrm{DM}$ & $60 \pm 43$ & 45 & 2087 & $108 \pm 37$ & 108 & 590 \\
\hline $\mathrm{K}_{2} \mathrm{O}$ & $\mathrm{g} \mathrm{kg}^{-1} \mathrm{DM}$ & $56 \pm 29$ & 52 & 1495 & $54 \pm 27$ & 50 & 578 \\
\hline $\mathrm{P}_{2} \mathrm{O}_{5}$ & $\mathrm{~g} \mathrm{~kg}^{-1} \mathrm{DM}$ & $35 \pm 18$ & 33 & 1555 & $41 \pm 16$ & 40 & 588 \\
\hline $\mathrm{Zn}$ & $\mathrm{mg} \mathrm{kg}{ }^{-1} \mathrm{DM}$ & $361 \pm 294$ & 300 & 1035 & $353 \pm 224$ & 296 & 487 \\
\hline $\mathrm{Cu}$ & $\mathrm{mg} \mathrm{kg}^{-1} \mathrm{DM}$ & $102 \pm 131$ & 71 & 1038 & $87 \pm 81$ & 60 & 487 \\
\hline $\mathrm{Hg}$ & $\mathrm{mg} \mathrm{kg}^{-1} \mathrm{DM}$ & $10.2 \times 10^{-2} \pm 13.2 \times 10^{-2}$ & $7 \times 10^{-2}$ & 984 & $10.5 \times 10^{-2} \pm 15.6 \times 10^{-2}$ & $7 \times 10^{-2}$ & 481 \\
\hline $\mathrm{N}_{\min } / \mathrm{TN}$ & $\%$ & $58 \pm 17$ & 57 & 1856 & $70 \pm 17$ & 68 & 590 \\
\hline $\mathrm{TOC} / \mathrm{TN}$ & - & $4.9 \pm 3.5$ & 3.9 & 1583 & $2.3 \pm 0.9$ & 2.3 & 587 \\
\hline
\end{tabular}

Literature Review

A dataset containing 180 datapoints of digestate (unseparated and LF) compositional properties was collected from 41 peer-reviewed articles found mainly via the ScienceDirect and Web of Science platforms. The following parameters were compiled: DM; OM; TOC; $\mathrm{TN}, \mathrm{NH}_{4}-\mathrm{N} ; \mathrm{P}_{2} \mathrm{O}_{5} ; \mathrm{K}_{2} \mathrm{O} ; \mathrm{Cu}$; and $\mathrm{Zn}$ [21-61]. The average compositional values can be found in Table A1 (Appendix A).

Sampling and Analysis Campaign

Fourteen digestate samples were collected from seven full-scale AD facilities throughout Europe (Belgium, Germany, Italy, The Netherlands, UK). These digestates were chosen for their relevance within the scope of the RENURE framework as suitable candidate materials, hence the samples were of either separated LF or unseparated digestate. All 
digestate samples were stored at $4{ }^{\circ} \mathrm{C}$ in polyethylene containers. DM was determined by placing triplicate samples at $105^{\circ} \mathrm{C}$ for $24 \mathrm{~h}$. The oven-dried samples were then placed in a muffle furnace at $550{ }^{\circ} \mathrm{C}$ for $4.5 \mathrm{~h}$ to determine $\mathrm{OM}$ content. $\mathrm{pH}-\mathrm{KCl}$ was measured with an Orion Star A211 pH meter in a 1/5 (w/v) ratio of fresh sample to $1 \mathrm{M} \mathrm{KCl}$. TN and TC were measured on a PRIMACS100 Analyzer series (Skalar B.V., Breda, The Netherlands). $\mathrm{NH}_{4}-\mathrm{N}$ and $\mathrm{NO}_{3}-\mathrm{N}$ were determined from digestate filtrates on a continuous flow auto-analyser (Chemlab System 4, Skalar). Previously, the samples were processed in a 1/5 (w/v) ratio of fresh digestate to $\mathrm{KCl}(1 \mathrm{M})$ and placed in an orbital shaker for $30^{\prime}$. The filtrates were obtained by pouring the $\mathrm{KCl}$ with digestate solutions over paper filters (Whatman No. 43). Macro- and micro elements were measured on an inductively coupled plasma emission spectrometer (ICP-OES) (Varian Vista-MPX, Palo Alto, CA, USA). The average results are listed in Table A2 (Appendix A).

Data Collection from Stakeholders

A call for data addressed to stakeholders from the biogas industry resulted in the collection of 23 confidential datapoints from Belgium, Czech Republic, France, Italy, Latvia, and Sweden. Some of these datapoints were averages from several digestate samples, several biogas plants, and in some cases averages over several years; the added value of these entries is thus higher than what the 23 datapoints let on. The average results are listed in Table A3 (Appendix A).

\subsection{Data Uniformization}

\subsubsection{Unit Conversions}

To ensure uniformity across all datasets, all values were expressed on a DM basis. Consequently, any source that expressed values on a FM basis was converted to DM. Conversely, whenever data were expressed as elemental $\mathrm{P}$ and $\mathrm{K}$, these were systematically converted to their oxide forms $-\mathrm{P}_{2} \mathrm{O}_{5}$ and $\mathrm{K}_{2} \mathrm{O}-$ using the respective multiplication factors of 2.29 and 1.20. Total solids and volatile solids were considered as DM and OM, respectively. Total Kjeldahl nitrogen was considered as $\mathrm{TN}$, as $\mathrm{NO}_{3}{ }^{-}$and nitrites $\left(\mathrm{NO}_{2}{ }^{-}\right)$ concentrations in digestate and LF of digestate can be considered negligible.

\subsubsection{TOC/OM Ratio}

Database A (Table 1) did not contain data on TOC, yet it contained 1831 usable entries on OM. As digestate is a heterogenous material that can contain varying amounts of TC and TOC stemming from different types of feedstocks, all the listwise entries pairing OM and TOC $(n=56)$ were gathered from database B to calculate a median TOC/OM ratio. This method resulted in a $0.55 \mathrm{TOC} / \mathrm{OM}$ conversion factor, which is almost on par with the value of 0.56 recommended for use in the FPR ((EU) 2019/1009). This conversion factor was then applied to database A to derive TOC values (Section 3.2).

\subsubsection{Mineral Nitrogen Content}

While database A (Table 1) did not contain information on $\mathrm{N}_{\min }$, it did include data on $\mathrm{NH}_{4}-\mathrm{N}$. Therefore, the assumption was made that $\mathrm{NH}_{4}-\mathrm{N}$ could be interchanged with $\mathrm{N}_{\min }$, as it is the predominant mineral form of $\mathrm{N}$ in digestate [15]. The same assumption was made in the RENURE study, where a 1:1 ratio for $\mathrm{NH}_{4}{ }^{+} / \mathrm{N}_{\min }$ was also considered.

\subsubsection{Decimal Places}

For RENURE compliance results, all values were rounded to one decimal place.

\section{Results}

\subsection{Database B}

The average results of digestate properties from (i) the literature review, (ii) the sampling campaign, and (iii) the data collection are presented in Table 1 (right). For DM, an unusually high value of $293 \mathrm{~g} \mathrm{~kg}^{-1} \mathrm{FM}$ was discarded. It was identified as digestate 
from organic household waste from a mesophilic digestion process [24], which in any case would not be eligible under the RENURE criteria. The interquartile range was 38 to $65 \mathrm{~g} \mathrm{~kg}^{-1} \mathrm{FM}$. Mean and median were 56 and $52 \pm 28 \mathrm{~g} \mathrm{~kg}^{-1} \mathrm{FM}$, respectively. Minimum and maximum values were 8 and $174 \mathrm{~g} \mathrm{~kg}^{-1} \mathrm{FM}$, respectively. Mean $\mathrm{pH}$ was 8 . An uncharacteristically low $\mathrm{pH}$ value of 5.6 for digested cattle slurry [28] was excluded. Mean $\mathrm{OM}$ was $652 \pm 94 \mathrm{~g} \mathrm{~kg}^{-1} \mathrm{DM}$ with a total range of 541 (minimum and maximum ranges were 354 and 895 , respectively).

Mean and median TOC values were 340 and $352 \pm 75 \mathrm{~g} \mathrm{~kg}^{-1} \mathrm{DM}$, respectively. For $\mathrm{N}$, the data compilation showed a mean TN value of $88 \pm 49 \mathrm{~g} \mathrm{~kg}^{-1} \mathrm{DM}$, ranging from 6 to 367. The latter value was reported for the LF of digested pig slurry processed via reverse osmosis [42], which may explain the exceptionally high value relative to other entries in the dataset. The second highest value $\left(229 \mathrm{~g} \mathrm{~kg}^{-1} \mathrm{DM}\right)$ was obtained via the same process and feedstock. These values, although high in comparison with the $78 \mathrm{~g} \mathrm{TN} \mathrm{kg}^{-1} \mathrm{DM}$ median value, were kept so as to avoid excluding any digestate upgrading technology, which could prove useful to meet RENURE criteria. One seemingly extreme outlier of $315 \mathrm{~g} \mathrm{NH}_{4}-\mathrm{N} \mathrm{kg}^{-1} \mathrm{DM}$ was discarded, which stemmed from confidential data shared by a stakeholder. Conversely, two low values ( 1 and $\left.2 \mathrm{~g} \mathrm{~kg}^{-1} \mathrm{DM}\right)$ were also excluded [24]. This resulted in a mean $\mathrm{NH}_{4}-\mathrm{N}$ of $59 \pm 40$ (46 median) with minimum and maximum values of 13 and $228 \mathrm{~g} \mathrm{NH}_{4}-\mathrm{N} \mathrm{kg}^{-1} \mathrm{DM}$, respectively. Mean $\mathrm{P}_{2} \mathrm{O}_{5}$ and $\mathrm{K}_{2} \mathrm{O}$ were $40 \pm 28$ and $60 \pm 35 \mathrm{~g} \mathrm{~kg}^{-1} \mathrm{DM}$, respectively.

Mean values for $\mathrm{Cu}$ and $\mathrm{Zn}$ were $233 \pm 368 \mathrm{mg} \mathrm{Cu} \mathrm{kg}^{-1} \mathrm{DM}$ (median 103) and $751 \pm 848 \mathrm{mg} \mathrm{Zn} \mathrm{kg}^{-1} \mathrm{DM}$ (median 425), respectively. In the case of $\mathrm{Cu}$, minimum and maximum values were 8.6 and $1682 \mathrm{mg} \mathrm{Cu} \mathrm{kg}^{-1} \mathrm{DM}$, respectively, with the stem and leaf plot considering anything above 741 as an extreme outlier. For $\mathrm{Zn}$, the total range was 0.2 to $3685 \mathrm{mg} \mathrm{Zn} \mathrm{kg}^{-1} \mathrm{DM}$, and anything above $2112 \mathrm{mg} \mathrm{Zn} \mathrm{kg}^{-1} \mathrm{DM}$ was flagged as extreme. For both $\mathrm{Cu}$ and $\mathrm{Zn}$, the flagged values stemmed from the same study [50] where anaerobically digested pig slurry was used. Albeit extreme, these values were kept nonetheless as references owing to known instances of pig manure containing high concentrations of these elements [62,63].

\subsection{Database A}

As mentioned in the 'Materials and Methods' section, the data collected in the section hereabove was compared to, and subsequently merged with, entries from database $\mathrm{A}$, in order to form the final database $C$ used in this study (Table 2). Potential outliers were defined using a 1.5 multiplication factor of the interquartile range as a first approximation. For DM, potential outliers were reported starting from $149 \mathrm{~g} \mathrm{~kg}^{-1} \mathrm{FM}$. However, database B (Table 1, right) displayed values ranging from 7.9 to $174 \mathrm{~g} \mathrm{~kg}^{-1} \mathrm{FM}$. Therefore, $175 \mathrm{~g} \mathrm{~kg}^{-1} \mathrm{FM}$ was chosen as the cut-off point, and anything above (values ranging from 176 up until $977 \mathrm{~g} \mathrm{~kg}^{-1} \mathrm{FM}$ ) was discarded as a probable SF, which was unlikely to meet the RENURE requirements. All the other compositional data associated with values above $175 \mathrm{~g} \mathrm{~kg}^{-1} \mathrm{FM}$ were also excluded from the database at this point. The resulting mean and median DM values for database A (Table 1, left) were 57 and $53 \pm 26 \mathrm{~g} \mathrm{~kg}^{-1} \mathrm{FM}$, respectively. For $\mathrm{pH}$, potential outliers were flagged below 7 and above 8.9. As the $\mathrm{pH}$ range in database $\mathrm{B}$ (Table 1, right) was between 6.9 and 9.0, all $\mathrm{pH}$ values within this range in database A (Table 1, left) were kept. This resulted in a final mean $\mathrm{pH}$ of $7.9 \pm 0.3$ for database A.

For OM, potential outliers were identified below the $360 \mathrm{~g} \mathrm{~kg}^{-1} \mathrm{DM}$ threshold, whereas minimum and maximum ranges in database $B$ (Table 1, right) were 354 and 895, respectively. To keep the data as representative as possible, the cut-off point was accordingly lowered to 354 , whereas the highest value of $690 \mathrm{~g} \mathrm{OM} \mathrm{kg}^{-1} \mathrm{DM}$ in database A was kept. As a result, mean and median OM were 699 and $707 \pm 106 \mathrm{~g} \mathrm{OM} \mathrm{kg}^{-1} \mathrm{DM}$, respectively. Database B contained 56 listwise entries pairing both OM and TOC with a mean TOC/OM of $54 \% \pm 9.3$ ( $55 \%$ median). Applying the median value to the 1831 entries on OM in database A (Table 1, left) resulted in an estimated mean value of $388 \pm 59 \mathrm{~g}^{\mathrm{TOC} \mathrm{kg}}{ }^{-1} \mathrm{DM}$ (393 median). 
The initial statistical screening identified values above $242 \mathrm{~g} \mathrm{TN} \mathrm{kg}^{-1} \mathrm{DM}$ as possible outliers in database A (Table 1, left). In database B, however (Table 1, right), the compiled data reported TN values ranging from 6.5 to 367 , the latter value corresponding to processed digestate via reverse osmosis. Consequently, the maximal limit was readjusted to $367 \mathrm{~g} \mathrm{TN} \mathrm{kg}^{-1} \mathrm{DM}$ in database A so as to include possible upgrading technologies that would typically result in higher $\mathrm{N}$ concentrations. The updated thresholds led to a mean and median of 102 and $89 \pm 53 \mathrm{~g} \mathrm{TN} \mathrm{kg}^{-1} \mathrm{DM}$. The exercise was repeated for $\mathrm{NH}_{4}-\mathrm{N}$, for which anything above $179 \mathrm{~g} \mathrm{~kg}^{-1} \mathrm{DM}$ was marked as a potential outlier. Turning to the compiled dataset from database B (Table 1, right), $\mathrm{NH}_{4}-\mathrm{N}$ values fell between 13 and $228 \mathrm{~g} \mathrm{NH}_{4}-\mathrm{N} \mathrm{kg}^{-1} \mathrm{DM}$. To avoid excluding valid entries, database A (Table 1, left) was thus expanded to include $\mathrm{NH}_{4}-\mathrm{N}$ entries up until $228 \mathrm{~g} \mathrm{NH}_{4}-\mathrm{N} \mathrm{kg}^{-1} \mathrm{DM}$. This led to a mean and median of 60 and $46 \pm 43 \mathrm{~g} \mathrm{NH}_{4}-\mathrm{N} \mathrm{kg}^{-1} \mathrm{DM}$, respectively.

Outliers were discarded in the same way for $\mathrm{K}_{2} \mathrm{O}$ and $\mathrm{P}_{2} \mathrm{O}_{5}$, for which the limits were determined at $117 \mathrm{~g} \mathrm{~K}_{2} \mathrm{O} \mathrm{kg}{ }^{-1} \mathrm{DM}$ and $79 \mathrm{~g} \mathrm{P}_{2} \mathrm{O}_{5} \mathrm{~kg}^{-1} \mathrm{DM}$, respectively. A maximum limit of $174 \mathrm{~g} \mathrm{~K}_{2} \mathrm{O} \mathrm{kg}^{-1} \mathrm{DM}$ in database B (Table 1, right) was traced back to the LF of digested pig manure from the sampling campaign. Still, in database B (Table 1, right), the highest $\mathrm{P}_{2} \mathrm{O}_{5}$ value, which was $159 \mathrm{~g} \mathrm{P}_{2} \mathrm{O}_{5} \mathrm{~kg}^{-1} \mathrm{DM}$, came from the literature review [50]. Therefore, the thresholds in database A (Table 1, left) were adjusted accordingly to reflect these upper limits, resulting in mean values of $55 \pm 29 \mathrm{~g} \mathrm{~K}_{2} \mathrm{O} \mathrm{kg}^{-1} \mathrm{DM}$ and $35 \pm 17 \mathrm{~g} \mathrm{P}_{2} \mathrm{O}_{5} \mathrm{~kg}^{-1} \mathrm{DM}$. The highest value for $\mathrm{Zn}$ in database A (Table 1, left) was $1831 \mathrm{mg} \mathrm{Zn} \mathrm{kg}^{-1} \mathrm{DM}$, whereas database B (Table 1, right) showed possible values of up to $3685 \mathrm{mg} \mathrm{Zn} \mathrm{kg}^{-1} \mathrm{DM}$. Consequently, all Zn entries from database A were kept, resulting in mean and median values of 347 and $299 \pm 239 \mathrm{mg} \mathrm{Zn} \mathrm{kg}^{-1} \mathrm{DM}$, respectively. For $\mathrm{Cu}$, an upper limit of $1682 \mathrm{mg} \mathrm{Cu} \mathrm{kg}^{-1} \mathrm{DM}$ was found in database B (Table 1, right), whereas one extreme outlier in database A (Table 1, left) was flagged at $1770 \mathrm{mg} \mathrm{Cu} \mathrm{kg}^{-1} \mathrm{DM}$. The latter value was thus kept in the dataset as a possible, albeit extreme, value (the second highest value was $798 \mathrm{mg} \mathrm{Cu} \mathrm{kg}^{-1} \mathrm{DM}$ ). The resulting mean and median values in database $\mathrm{A}$ were 97 and $70 \pm 108 \mathrm{mg} \mathrm{Cu} \mathrm{kg}^{-1} \mathrm{DM}$, respectively.

\subsection{Database C}

The screened results from databases A $(n=2114)$ and $B(n=194)$ were subsequently combined to form database $C(n=2308)$, considered as the final database representative of digestate compositional ranges used for this study. Mean and median results of database $C$, upon which all subsequent analyses were based, are shown in Table 2 (left). The frequency distributions of DM, OM, TOC, TN, $\mathrm{N}_{\min }\left(\mathrm{NH}_{4}-\mathrm{N}\right), \mathrm{Zn}, \mathrm{Cu}$, and $\mathrm{Hg}$ are presented in Figure 2.

The mean $\mathrm{N}_{\min } / \mathrm{TN}$ value from the final dataset was $58 \pm 17(\mathrm{n}=1856)$, with a 57 median. For TOC/TN, mean and median values were 4.9 and $3.9 \pm 3.5(\mathrm{n}=1583)$. Regarding $\mathrm{HMs}$, the final values were $361 \pm 294 \mathrm{mg} \mathrm{Zn} \mathrm{kg}^{-1} \mathrm{DM}(\mathrm{n}=1035) ; 102 \pm 131 \mathrm{mg} \mathrm{Cu} \mathrm{kg}^{-1} \mathrm{DM}$ ( $\mathrm{n}=1038)$; and $10 \times 10^{-2} \pm 13 \times 10^{-2} \mathrm{mg} \mathrm{Hg} \mathrm{kg}^{-1} \mathrm{DM}(\mathrm{n}=984)$. The average compositional properties of the digestate cases that complied with either $\mathrm{N}_{\min } / \mathrm{TN} \geq 90 \%$ or $\mathrm{TOC} / \mathrm{TN} \leq 3$ are also presented (Table 2 , right). Under these criteria, it can be observed that the DM content dropped from 5.3\% to 3.5\% FM (median values), while median TOC/TN and $\mathrm{N}_{\min } / \mathrm{TN}$ went from 3.9 to 2.3 and 57 to $68 \%$, respectively.

A more detailed look at RENURE compliance showed that $5 \%$ of the datapoints ( $\mathrm{n}=1856$ ) met the $\mathrm{N}_{\min } / \mathrm{TN} \geq 90 \%$ criterion, $36 \%$ met the TOC $/ \mathrm{TN} \leq 3$ criterion $(\mathrm{n}=1583)$, while $32 \%(n=1893)$ met either one or the other criterion (further discussed in Section 4.4). Regarding HMs, 95\% met either $\leq 300 \mathrm{mg} \mathrm{Cu} \mathrm{kg}^{-1} \mathrm{DM}(\mathrm{n}=1038)$ or $\leq 800 \mathrm{mg} \mathrm{Zn} \mathrm{kg}^{-1}$ $\mathrm{DM}(\mathrm{n}=1035)$ (further discussed in Section 4.3). 


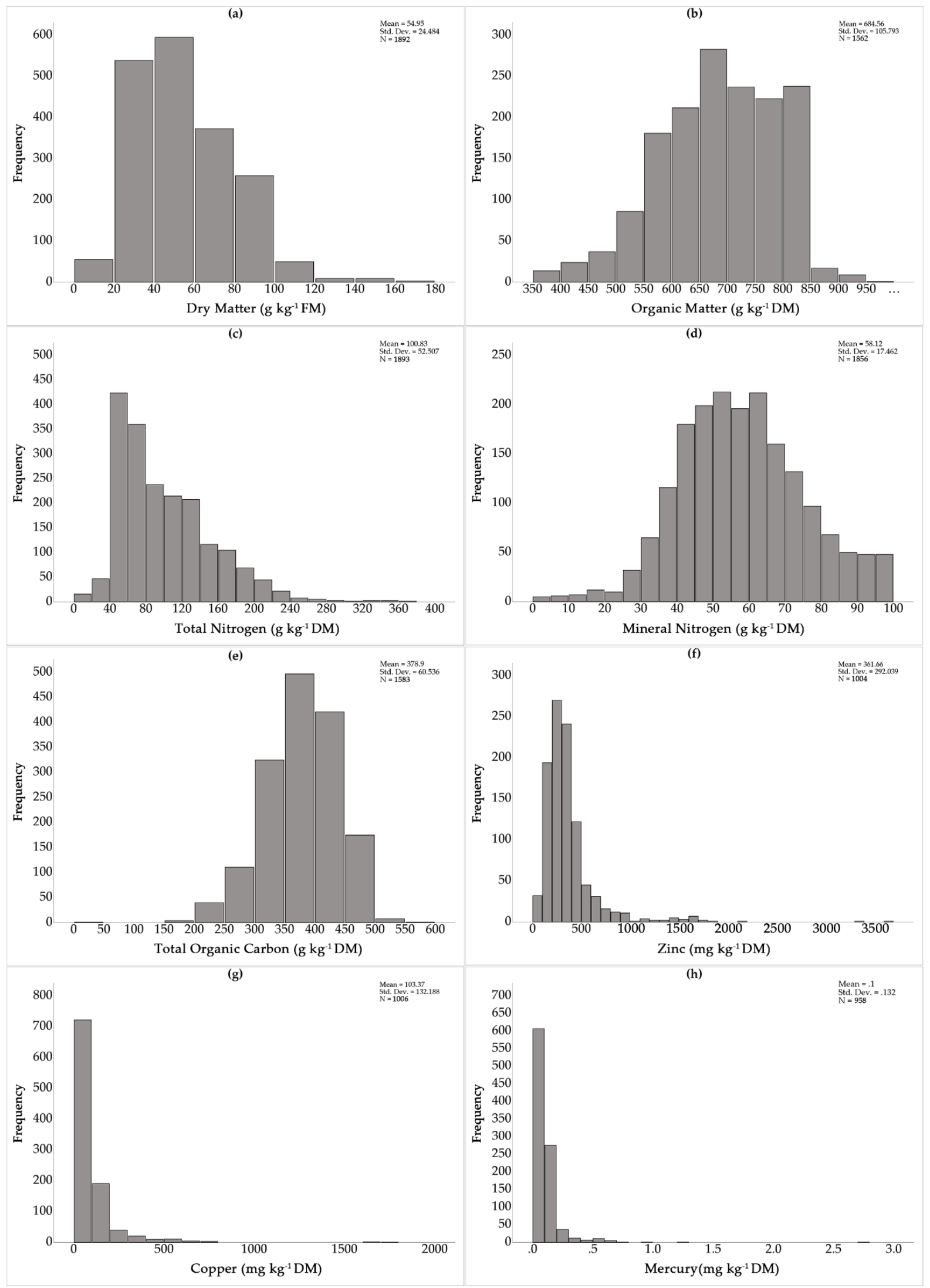

Figure 2. Database C's frequency distribution for (a) dry matter; (b) organic matter; (c) total nitrogen; (d) mineral nitrogen; (e) total organic carbon; (f) zinc; (g) copper; and (h) mercury. Here, $\mathrm{n}=$ digestate sample size. 


\section{Discussion}

\subsection{Broad Range of Digestate and Feedstock Characteristics}

As a result of digestate chemical properties covering such broad ranges, it was expected that compositional data were in most cases not normally distributed (Shapiro-Wilk test). Conversely, information on whether a separation technology was used (sedimentation, belt press, screw press, centrifugation) was not available from database A (Table 1, left), which further complicated any type of categorisation. Therefore, to err on the side of caution, digestate entries were treated as a whole, as possibly containing a mix of raw and LF of digestate based on the DM content (Section 2.1.1).

\subsection{Gross Estimation of Nutrients and Carbon Potential from Digestate}

The yearly amount of animal manure in Europe is estimated at $1400 \mathrm{Mt}$ [64], which carries with it an energy potential from biogas of 0.64 to $0.92 \mathrm{PJ}$ [65], while the energy of combined agricultural feedstocks (manure, grass, and straw) has been shown to lie between 1.2 and $2.3 \times 10^{3} \mathrm{PJ}$ in the EU in 2030 [66]. With an estimated $180 \mathrm{Mt}$ of digestate produced in the EU-28 each year [67], it is believed that less than $8 \%$ of the livestock manure in the EU finds its way to processing facilities [64]. This indicates that, on one hand, there is still significant leeway to increase GHG emission abatement from manure by way of biogas production $[11,68]$ and, on the other hand, that there is still room for growth for nutrient recovery and recycling.

As an order of magnitude, the amount of $180 \mathrm{Mt}$ fresh digestate produced yearly in the EU-28 [67] was used as a starting point to provide a ballpark estimate of the nutrients and $C$ potential it might contain. Based on the assumptions made in this study, the 10th and 90th percentiles from database $\mathrm{C}$ characteristics (Table 2) were used as lower and upper ranges, respectively. It was thus calculated that $180 \mathrm{Mt}$ digestate could contain anywhere between $5 \mathrm{Mt}$ and $16.5 \mathrm{Mt} \mathrm{DM}$. In turn, this amount of DM was shown to potentially contain between 2.8 and 13.6 Mt OM; 1.5 and 7.5 Mt TOC; 0.25 to $2.9 \mathrm{Mt} \mathrm{TN} ; 0.09$ to $2.1 \mathrm{Mt} \mathrm{N}_{\min } ; 0.1$ to $1.5 \mathrm{Mt} \mathrm{K}{ }_{2} \mathrm{O}$; and 0.08 to $0.9 \mathrm{Mt}_{2} \mathrm{O}_{5}$ (Table 3). With a $9 \%$ increase since 2010, chemical $\mathrm{N}$ fertiliser consumption was estimated at 11.6 Mt in the EU-28 in 2017 [69]. The median and upper values for $\mathrm{N}_{\min }$ (Table 3) would suggest a gross potential from digestate as substitute to Haber-Bosch-derived chemical N-based fertilisers of approximately 4 to $18 \%$ (excluding ammonia volatilisation and NFRV), thereby also decreasing the high energy consumption and carbon dioxide emissions associated with the process. Precision injection techniques have been shown to reduce ammonia $\left(\mathrm{NH}_{3}\right)$ losses; therefore, subtracting a mean approximate value of $10 \%$ of the total ammoniacal nitrogen, if precision injection were to be used [51,70], would lead to a corrected estimate ranging from 3 to $16 \%$ of total $\mathrm{N}_{\text {min }}$ consumption. Factoring in a replacement value of $82 \%$, which was the average NFRV associated with the $90 \%$ to $100 \% \mathrm{~N}_{\min } / \mathrm{TN}$ pool in the RENURE metanalysis [12], would theoretically result in a gross $\mathrm{N}$ substitute value of 3 to $13 \%$ (assuming all digestates meet the RENURE criteria). Nevertheless, if the $32 \%$ compliance rate (Table 4 ) is any indication, then a more realistic $\mathrm{N}_{\min }$ replacement value in the current state of affairs, at least in NVZs, would be 1 to $4 \%$ when considering the estimated $180 \mathrm{Mt}$ fresh digestate. With $P$ having been placed on the list of 20 critical raw materials by the EC and considering the possibilities for sustainable use and recycling thereof via $\mathrm{AD}, \mathrm{P}$ from digestate would represent roughly (when converted to its elemental form) 0.04 to $0.4 \mathrm{Mt} \mathrm{P}$, thus representing, based on the 1.2 Mt P consumed in the EU-28 in 2017 [69], between 3 and 33\% in P savings. Furthermore, the AD of feedstocks will have converted between 20 and $95 \%$ of the ingoing OM into biogas [15]; therefore, the estimated 1.5 to $7.5 \mathrm{Mt} \mathrm{TOC} \mathrm{(Table} \mathrm{3)} \mathrm{is} \mathrm{likely} \mathrm{to} \mathrm{be}$ in a more stable form. This residual $\mathrm{C}$ can thus be considered to have a higher potential for sequestration in the form of soil organic carbon [71] and could thus yield considerable environmental benefits. 
Table 3. Estimation of gross potential of nutrients and C, on a dry matter basis, contained in a yearly estimate of $180 \mathrm{Mt}$ of digestate. Here, $\mathrm{Mt}=$ megatonnes; $\mathrm{kt}=$ kilotonnes; $\mathrm{FM}=$ fresh matter; $\mathrm{DM}=\mathrm{dry}$ matter; $\mathrm{OM}=$ organic matter; $\mathrm{TOC}=$ total organic carbon; $\mathrm{TN}=$ total nitrogen; $\mathrm{N}_{\text {min }}=$ mineral nitrogen; $\mathrm{K}_{2} \mathrm{O}=$ potassium oxide; $\mathrm{P}_{2} \mathrm{O}_{5}=$ phosphorus pentoxide.

\begin{tabular}{|c|c|c|c|}
\hline \multirow{3}{*}{ Parameter } & \multicolumn{3}{|c|}{$180 \mathrm{Mt} \mathrm{FM} \mathrm{y}^{-1}$ Digestate } \\
\hline & \multicolumn{3}{|c|}{ kt $y^{-1}$ Equivalent } \\
\hline & 10th Percentile & Median & 90th Percentile \\
\hline DM & 5040 & 9540 & 16,506 \\
\hline $\mathrm{OM}$ & 2787 & 6726 & 13,551 \\
\hline TOC & 1547 & 3730 & 7527 \\
\hline $\mathrm{TN}$ & 247 & 830 & 2856 \\
\hline $\mathrm{N}_{\min }\left(\mathrm{NH}_{4}-\mathrm{N}\right)$ & 86 & 429 & 2096 \\
\hline $\mathrm{K}_{2} \mathrm{O}$ & 111 & 496 & 1519 \\
\hline $\mathrm{P}_{2} \mathrm{O}_{5}$ & 81 & 315 & 924 \\
\hline
\end{tabular}

Table 4. Compliance of digestate under the current proposed RENURE criteria. Here, $\mathrm{Cu}=$ copper; $\mathrm{Zn}=\mathrm{zinc} ; \mathrm{TOC}=$ total organic carbon; $\mathrm{TN}$ = total nitrogen; $\mathrm{N}_{\min }=$ mineral nitrogen; $\mathrm{DM}=$ dry matter.

\begin{tabular}{|c|c|c|c|c|c|}
\hline & $\leq 300 \mathrm{mg} \mathrm{Cu} \mathrm{kg}^{-1} \mathrm{DM}$ & $\leq 800 \mathrm{mg} \mathrm{Zn} \mathrm{kg}{ }^{-1} \mathrm{DM}$ & $\mathrm{N}_{\min } / \mathrm{TN} \geq 90 \%$ & $\mathrm{TOC} / \mathrm{TN} \leq 3$ & $\begin{array}{l}\mathrm{N}_{\min } / \mathrm{TN} \geq 90 \% \\
\text { or } \mathrm{TOC} / \mathrm{TN} \leq 3\end{array}$ \\
\hline Compliance (cases) & $986 / 1038$ & $980 / 1035$ & $96 / 1856$ & $574 / 1583$ & $606 / 1893$ \\
\hline Compliance (\%) & 95 & 95 & 5 & 36 & 32 \\
\hline
\end{tabular}

\subsection{Compliance with $\leq 300 \mathrm{mg} \mathrm{Cu} \mathrm{kg}^{-1} \mathrm{DM}$ and $\leq 800 \mathrm{mg} \mathrm{Zn} \mathrm{kg}^{-1} \mathrm{DM}$ Criteria}

Many investigations showed that $\mathrm{Cu}$ and $\mathrm{Zn}$ concentrations in pig manure could be significantly higher than for other types of animal manures as a result of these microelements being added to feed to stimulate growth [62,72]. Understandably, these microelements were kept as RENURE criteria as their presence in excess can lead to adverse effects on the environment (soil contamination) and human health (food contamination). However, in adequate amounts, $\mathrm{Cu}$ and $\mathrm{Zn}$ are essential cofactors in various physiological processes in plants [73,74]. The average $\mathrm{Zn}$ and $\mathrm{Cu}$ concentrations reported in the Joint Research Centre's (JRC) sampling campaign for LF of digestate were 357 and $127 \mathrm{mg} \mathrm{kg}^{-1} \mathrm{DM}$ [12], respectively, against 361 and $102 \mathrm{mg} \mathrm{kg}^{-1} \mathrm{DM}$ in this study (Table 2, left).

The three highest values in the final database $C$ (Table 2, left)—ranging from 2112 to $3685 \mathrm{mg} \mathrm{Zn} \mathrm{kg}^{-1} \mathrm{DM}$ - were from the literature review and were positively identified as digestate from pig slurries. The fourth highest value, $1831 \mathrm{mg} \mathrm{Zn} \mathrm{kg}^{-1} \mathrm{DM}$, was traced back to database $\mathrm{A}$ (Table 1), although information on the type of animal manure was not available. For $\mathrm{Cu}$, the highest value $-1770 \mathrm{mg} \mathrm{Cu} \mathrm{kg}^{-1} \mathrm{DM}-$ came from database A (for which the type of animal manure is not specified). The second and third highest concentrations (1611 and $1682 \mathrm{mg} \mathrm{Cu} \mathrm{kg}^{-1} \mathrm{DM}$ ) came from the literature review and were linked to digested pig manure. In other terms, when the information was available in the database, the highest values for $\mathrm{Cu}$ and $\mathrm{Zn}$ were usually associated with pig manure, which tends to justify the need for additional scrutiny for these elements. The majority of entries in database C (Table 2, left) came from database A (Table 1), for which information on the type of manure (pig, bovine, poultry) is not specified. So, while a further categorisation of the types of manure cannot be ascertained, the results from this study tend to show that $\mathrm{Cu}$ and $\mathrm{Zn}$ from co-digested manure mostly met the RENURE criteria, and thus would not pose any environmental risk: $5.3 \%$ of the 1035 considered cases were above the $800 \mathrm{mg} \mathrm{Zn} \mathrm{kg}^{-1}$ DM limit; $5.0 \%$ of the 1038 available cases for $\mathrm{Cu}$ were above the $300 \mathrm{mg} \mathrm{Cu} \mathrm{kg}^{-1} \mathrm{DM}$ limit (Table 4). 


\subsection{Compliance with $N_{\min } / T N \geq 90 \%$ or TOC/TN $\leq 3$ RENURE Criteria}

When considering the $\mathrm{N}_{\min } / \mathrm{TN} \geq 90 \%$ criterion, $5.2 \%$ of the cases met the requirement, i.e., 96 of the 1856 cases presented values of $90 \%$ or higher (Table 4). When applying the TOC/TN $\leq 3$ criterion, $36.3 \%$ of the total 1583 considered cases met the proposed requirement. Total compliance, taking into account both criteria, was $32 \%$.

In the JRC study, candidate RENURE product characterisation pointed towards the TOC/TN criterion displaying slightly more flexibility than the $\mathrm{N}_{\min } / \mathrm{TN}$ criterion, though in all likelihood, not to the scale observed in Table 4 (7:1 ratio). For the cases that complied with either of the RENURE criteria, the median TOC/TN value was 2.3 (Table 2, right), indicating that most entries already found themselves in the upper tier of the allowed range.

The TOC $/ \mathrm{TN} \leq 3$ criterion was applied to a listwise comparison of all entries containing data on both RENURE criteria $(\mathrm{n}=1546)$. The resulting 558 compliant cases $(36 \%$ overall compliance) had mean and median TN values of 157 and $152 \pm 37 \mathrm{~g} \mathrm{~kg}^{-1} \mathrm{DM}$, respectively, and $\mathrm{N}_{\min } / \mathrm{TN}$ values of 68 and $67 \pm 16 \%$, respectively, thereby already indicating that most digestates that met the TOC/TN criterion would not qualify under the $90 \%$ $\mathrm{N}_{\min }$ /TN threshold. In fact, of the 558 cases that complied with TOC/TN $\leq 3$, less than $10 \%$ (53 cases) also complied with the $\mathrm{N}_{\min } / \mathrm{TN} \geq 90 \%$ criterion. Conversely, applying the $\mathrm{N}_{\min } / \mathrm{TN} \geq 90 \%$ criterion to the 1546 listwise cases returned 77 compliant entries, of which $69 \%$ (53 cases) also complied with the TOC/TN $\leq 3$ criterion. This seemed to confirm that, on one hand, the studied digestate cases were far more likely to qualify under the TOC/TN criterion than the $\mathrm{N}_{\min } / \mathrm{TN}$ one and, on the other hand, that the cases that complied with $\mathrm{N}_{\min } / \mathrm{TN}$ were also more likely to meet the TOC/TN criterion.

\subsection{Dry Matter Content of RENURE Compliant Digestates}

Looking at the DM content of the cases that were below or equal to TOC/TN $\leq 3$, there was no apparent linear correlation between DM and TOC/TN $\left(R^{2}=0.218\right)$. Nonetheless, it could be observed that the DM values dropped noticeably-with mean and median values of 38 and $35 \pm 14 \mathrm{~g} \mathrm{~kg}^{-1} \mathrm{FM}$, respectively-in comparison with the entries that were above TOC/TN $\leq 3$, which displayed mean and median values of 65 and $62 \pm 24$, respectively. The same drop in DM content was observed for the $\mathrm{N}_{\min } / \mathrm{TN}$ criterion, for which mean and median values of digestate entries above or equal to $90 \% \mathrm{~N}_{\min } / \mathrm{TN}$ were 34 and $32 \pm 13 \mathrm{~g} \mathrm{~kg}^{-1} \mathrm{FM}$, respectively. The cases that met either $\mathrm{N}_{\min } / \mathrm{TN} \geq 90 \%$ or the TOC/TN $\leq 3$ returned mean and median DM values of 38 and $35 \pm 14 \mathrm{~g} \mathrm{~kg}^{-1} \mathrm{FM}$, respectively, against 57 and $53 \pm 26 \mathrm{~g} \mathrm{~kg}^{-1} \mathrm{FM}$, respectively, in database $C$ (Table 2, left), i.e., a drop in DM content of over 30\%. Thus, while it cannot be ruled out that some unseparated digestates successfully met the criteria, a median value of $3.5 \%$ DM would typically suggest that the digestate underwent some form of separation resulting in a LF and possibly an additional processing treatment (stripping, scrubbing). This trend is visible in the boxplots in Figure 3, where it can be observed that the datapoints with lower DM ranges are in general more successful in meeting either the TOC/TN or $\mathrm{N}_{\min } / \mathrm{TN}$ requirements.

\subsection{Identified LF Cases and Associated Separation Technologies}

There are 58 known cases (Table 5) in which the LF of digestate is mentioned explicitly, either from the experimental assays-for which background information on each process is known in detail—or the literature review—in which a technology was explicitly mentioned. Of these 58 entries, 26 contained data both on TOC/TN and $\mathrm{N}_{\min } / \mathrm{TN}$, and 49 contained data on $\mathrm{N}_{\min } / \mathrm{TN}$. The distribution of cases according to separation technology and RENURE criterion is presented in Table 5. 


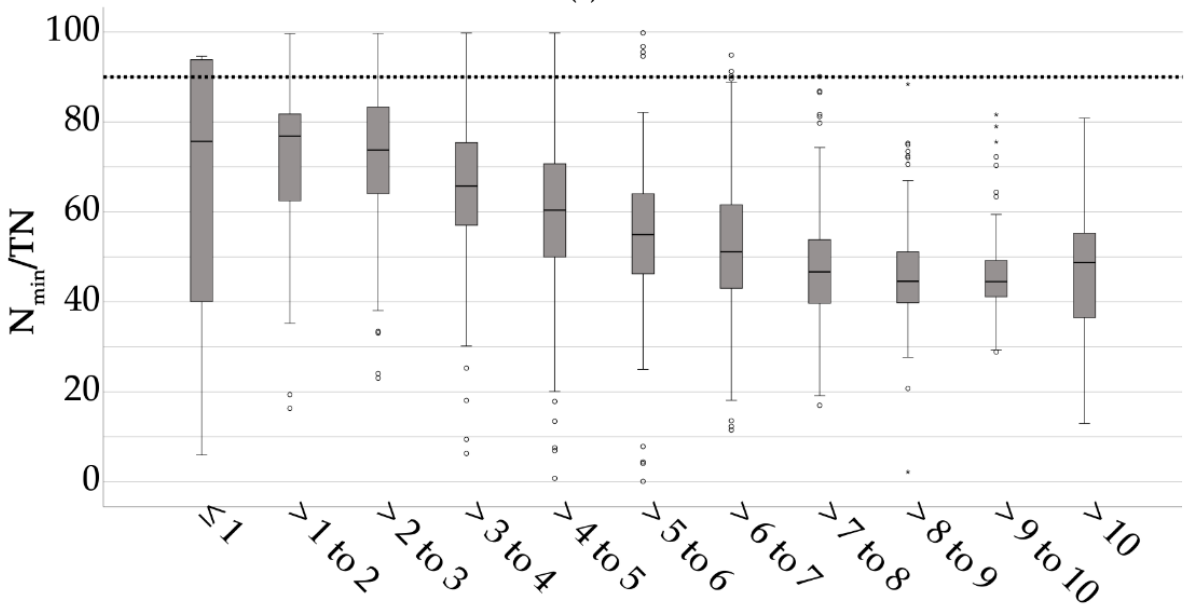

(b)

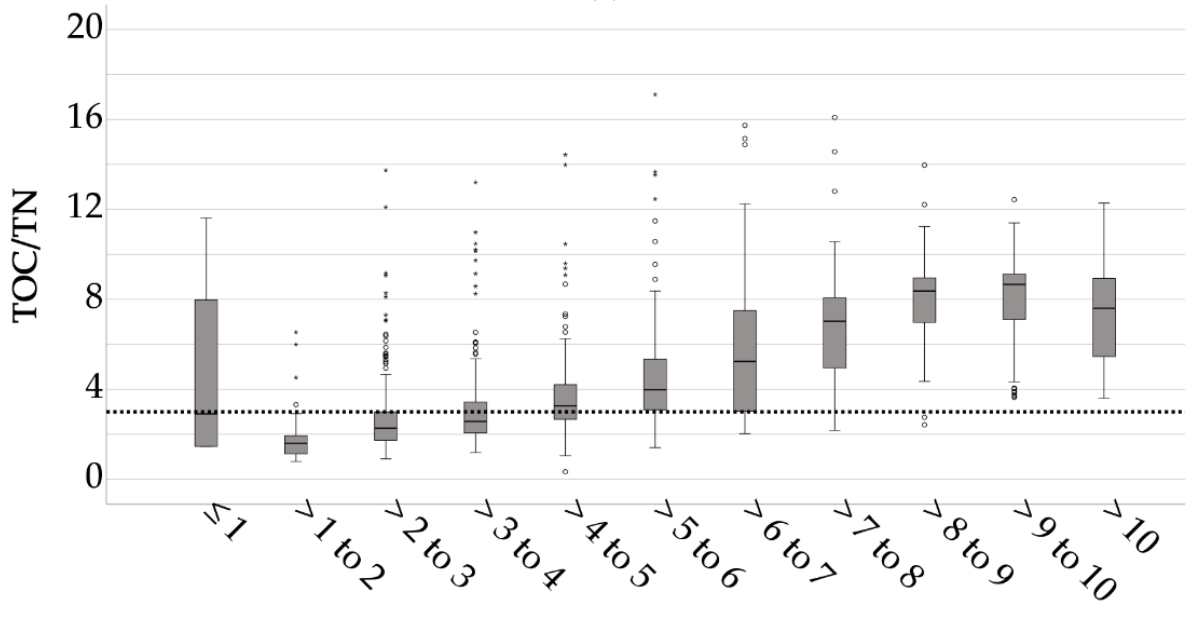

Dry matter range $(\% \mathrm{FM})$

Figure 3. Box plot distribution of (a) $\mathrm{N}_{\mathrm{min}} / \mathrm{TN}$ and (b) TOC/TN (excluding seven entries with TOC $/ \mathrm{TN}>20$ ) by dry matter range. In both graphs, the dotted line marks the RENURE threshold.

Table 5. Overview of the number of identified LF entries in the database per separation technology and RENURE compliance. Here, $\mathrm{TOC}=$ total organic carbon; $\mathrm{TN}=$ total nitrogen; $\mathrm{N}_{\min }=$ mineral nitrogen.

\begin{tabular}{cccccccc}
\hline & & \multicolumn{5}{c}{ Separation Technology } \\
\hline \multirow{2}{*}{ Renure Criterion } & Compliance & Reverse Osmosis & Screw Press & Decanter & Centrifuge & Belt Press & Unspecified \\
\hline \multirow{2}{*}{$\mathrm{N}_{\mathrm{min}} / \mathrm{TN}$} & Cases & $2 / 4$ & $0 / 30$ & $0 / 3$ & $0 / 4$ & $0 / 3$ & $0 / 5$ \\
& $(\%)$ & 50 & 0 & 0 & 0 & 0 & 0 \\
\hline \multirow{2}{*}{$\mathrm{TOC} / \mathrm{TN}$} & Cases & - & $4 / 13$ & $1 / 3$ & $3 / 4$ & $0 / 2$ & $2 / 4$ \\
& $(\%)$ & - & 31 & 33 & 75 & 0 & 50 \\
\hline
\end{tabular}

For the TOC/TN criterion, 10 out of the 26 available cases (38\%) displayed a value below or equal to 3 . The associated separation technologies were screw press, centrifuge, decanter, and unspecified technology. The $\mathrm{N}_{\min } / \mathrm{TN} \geq 90 \%$ criterion appeared more discriminatory than the TOC/TN $\leq 3$ factor as only 2 of the 49 cases qualified (4\%): both being mineral concentrates from the reverse osmosis of digested pig slurry. The technologies associated with the remaining 47 LF entries were screw press, centrifuge, belt press, decanter, and reverse osmosis. Of the 30 known cases that resorted to a screw press, none qualified under the $\mathrm{N}_{\min } / \mathrm{TN}$ criterion. Moreover, of these 30 cases, 13 had corresponding data on TOC/TN, of which 4 met the criterion, seemingly showcasing the 
greater tolerance of the TOC/TN criterion over $\mathrm{N}_{\min } / \mathrm{TN}$, as was already pointed out in Table 4. Overall, out of 26 known LF cases that contained data on both RENURE criteria, 10 met one or the other requirement. These results are in the same order of magnitude as those reported in the RENURE document: $0 \%$ compliance for screw press against $13 \%$ in this study; $80 \%$ after centrifuge or enhanced solids removal against $75 \%$ in this study; $50 \%$ for LF against 38\% in this study [12]. While it is outside of the scope of this study to pinpoint clear-cut favourite technologies, i.e., producing biofertilisers that would meet the proposed RENURE criteria, as highlighted in Table 5, not all mechanical separation technologies are made equal, as indeed, some have superior solids' removal efficiency than others [19]. These results (Table 5) agree with the RENURE study, which had already noted that further refining steps involving membrane separation (reverse osmosis, micro-, or ultrafiltration) and nutrient stripping would probably be a prerequisite to reach the necessary $\mathrm{N}_{\min }$ concentrations and/or remove sufficient OM.

\subsection{RENURE Compliance of the Targeted LF in the Database}

As mentioned in Section 2.1.1., two methods were employed to target the LF within the digestate database. In the first, DM ranges of LF reported in the literature were used $[15,18,23]$. These values, ranging from 14 to $66 \mathrm{~g} \mathrm{~kg}^{-1} \mathrm{FM}$, were applied to the database as possibly representing LF of digestate. This resulted in 1324 entries containing data on TOC/TN or $\mathrm{N}_{\mathrm{min}} / \mathrm{TN}$. Regarding TOC/TN, mean and median values dropped from 4.9 and 3.9, respectively, in database $C$ (Table 2, left) to 3.8 and 3.0, respectively, showcasing a 50\% compliance rate (Table 6, left). For $\mathrm{N}_{\min } / \mathrm{TN}$, mean and median values increased from 58 and 57 (Table 2, left), respectively, to 63 and 62\%, respectively, reaching a $7 \%$ compliance. Total compliance (both criteria together) was $43 \%$. Incidentally, no notable differences in $\mathrm{Cu}$ and $\mathrm{Zn}$ concentrations or compliance were observed in the targeted LF population in comparison with the results reported in Table 2. For $\mathrm{Cu}$, median was $70 \pm 118 \mathrm{mg} \mathrm{Cu} \mathrm{kg}^{-1} \mathrm{DM}$ (96\% compliance) and, for $\mathrm{Zn}$, median was $309 \pm 261 \mathrm{mg} \mathrm{Zn} \mathrm{kg}^{-1}$ DM (96\% compliance).

Table 6. RENURE compliance of targeted LF of digestate, based on DM range. Left: DM ranges associated with LF reported in literature; right: DM ranges from identified LF cases in the database (using median value as cut-off point). Here, $\mathrm{TOC}=$ total organic carbon; $\mathrm{TN}=$ total nitrogen; $\mathrm{N}_{\min }=$ mineral nitrogen; $\mathrm{DM}=$ dry matter.

\begin{tabular}{|c|c|c|c|c|c|c|}
\hline & \multicolumn{3}{|c|}{ (Left) DM Range: 14 to $66 \mathrm{~g} \mathrm{~kg}^{-1} \mathrm{FM}$} & \multicolumn{3}{|c|}{ (Right) DM Range: 1.5 to $44 \mathrm{~g} \mathrm{~kg}^{-1} \mathrm{FM}$} \\
\hline & $\mathrm{N}_{\min } / \mathrm{TN} \geq 90 \%$ & $\mathrm{TOC} / \mathrm{TN} \leq 3$ & $\begin{array}{l}\mathrm{N}_{\min } / \mathrm{TN} \geq 90 \% \\
\text { or TOC/TN } \leq 3\end{array}$ & $\mathrm{~N}_{\min } / \mathrm{TN} \geq \mathbf{9 0} \%$ & $\mathrm{TOC} / \mathrm{TN} \leq 3$ & $\begin{array}{l}\mathrm{N}_{\min } / \mathrm{TN} \geq 90 \% \\
\text { or } \mathrm{TOC} / \mathrm{TN} \leq 3\end{array}$ \\
\hline Compliance (cases) & $90 / 1291$ & $548 / 1087$ & $575 / 1324$ & $76 / 745$ & $424 / 658$ & $444 / 770$ \\
\hline Compliance (\%) & 7 & 52 & 43 & 10 & 64 & 58 \\
\hline
\end{tabular}

In the second method, to try and further isolate the LF in the database, the median DM value of $44.9 \mathrm{~g} \mathrm{~kg}^{-1} \mathrm{FM}$ from the 58 known cases of LF in the database (reported in Table 5) was used as the cut-off point. This resulted in a targeted DM range between 1.4 (lowest value in database C) and $44.9 \mathrm{~g} \mathrm{~kg}^{-1} \mathrm{FM}$ (cut-off). Further lowering the DM range resulted in a higher RENURE compliance across all criteria, taken either separately or together. However, a similar gap between compliance with TOC/TN (64\%) or $\mathrm{N}_{\min } / \mathrm{TN}(10 \%)$ was observed once more, while overall compliance (both criteria together) was the highest of all at 58\%. Thus, it might be argued that narrowing the scope, based on lower DM ranges, was effective in targeting the LF in the database as RENURE compliance increased substantially with both methods explained above (Table 6).

\subsection{Best Management Practices: Reaping Optimal Benefits and Minimising Environmental Risks}

In the RENURE study, the proposed threshold values for $\mathrm{N}_{\min } / \mathrm{TN}$ and TOC/TN were based on the respective NFRV of the potential candidate RENURE fertilisers, where the highest observed NFRV values (82 and 83\% mean, respectively) corresponded to the 
90 to $100 \% \mathrm{~N}_{\min } / \mathrm{TN}$ pool and the 0 to $3 \mathrm{TOC} / \mathrm{TN}$ pool. The high correlation between the top tier NFRV values of candidate fertilisers and the proposed criteria of $\mathrm{N}_{\min } / \mathrm{TN} \geq 90 \%$ and TOC/TN $\leq 3$ meant that the door was left open for a candidate product to meet either one or the other, so as to allow more flexibility. In this study, the close scrutiny of digestate properties uncovered a trend in which the TOC/TN criterion appeared less restrictive than the $\mathrm{N}_{\min } / \mathrm{TN}$ criterion (Tables 4 and 6). As discussed above, a listwise comparison of both criteria returned a median value of $\mathrm{N}_{\min } / \mathrm{TN}$ of $67 \%$ for digestates that had met the $\mathrm{TOC} / \mathrm{TN} \leq 3$ threshold. As a result, while available field-based evidence suggests that the use of digestate can lead to similar amounts of residual $\mathrm{NO}_{3}{ }^{-}$in the soil and NFRV as that of chemical fertilisers [14], and in some cases even lead to reduced $\mathrm{NO}_{3}{ }^{-}$leaching [75], the fact that considerably more digestates complied with TOC/TN than $\mathrm{N}_{\min } / \mathrm{TN}$ in this study (Tables 4 and 6) might warrant further research into the interaction between soil-plant systems in relation to both criteria for any given digestate product.

A higher presence of the plant-available $\mathrm{NH}_{4}-\mathrm{N}$ form and a lower $\mathrm{C} / \mathrm{N}$ ratio [52] have led to instances of superior short-term fertility of digestate over undigested feedstocks [76] and, in some cases, to similar biomass yields to those obtained with chemical fertilisers $[34,77,78]$. However, the optimal time of application remains a challenge. In particular, autumn application of digestate, when crop uptake has slowed to a crawl, has been shown to substantially increase $\mathrm{N}$ volatilisation and $\mathrm{NO}_{3}{ }^{-}$leaching [79], both of which can be further exacerbated on sandy soils with low water retention capacity. Digestate fertilisation in NVZ takes place from late winter through to the end of summer, starting at the earliest in February when plant N-demand is still low and mineralisation is slow because of the low soil temperatures. Thus, a better grasp of the interaction between TOC/TN and $\mathrm{N}_{\min } / \mathrm{TN}$ for a specific soil-plant system might help in determining the optimal time of application (thereby increasing NUE and NFRV), where it might be argued that a combination of N fertiliser from both mineral (immediate availability) and organic forms (delayed availability) might be preferable for early spring crops; whereas for summer crops, the high mineralisation activity and ensuing higher NUE would mean that reliance on digestate with a higher organic load would cover the plant's demands [80] without jeopardising the environment. Another path worth exploring is the use of catch crops to effectively reduce nutrients' runoff and leaching. In this respect, evidence was provided that the ensiling and subsequent co-digestion of catch crops with manure was an economically viable way to increase biogas production [81], all the while improving nutrient recycling and bringing grist to the mill of the circular economy.

The compositional properties of digestate can vary substantially according to a.o. processing technology, retention time, organic loading rate, digestion temperature, composition (cellulose, hemicellulose, and lignin), and ratio of the (co)digested feedstocks [82]. The management system - from collection to storage-also affects the compositional value of slurries and manure, which contain varying amounts of urine, water, faeces, and spilt feed, and will also depend on the diet, the growth stage, and the species [19]. So, the resulting wide range of digestate properties combined with the further breakdown and release of its organically bound nutrients can result in unpredictable $\mathrm{N}$ dynamics in which the mineralised $\mathrm{N}$ exceeds crop demands, giving rise to $\mathrm{N}$ leaching $[44,83]$. Furthermore, the influence of soil texture (sandy, loamy, clayey) and SOM content was also shown to influence $\mathrm{NH}_{3}$ volatilisation [84-86].

If we take all of the above into consideration, the variability of $\mathrm{N}$ kinetics from digestate makes a convincing case for the RENURE limits to be considered in tandem with best management practices adapted to the local context. These include, among others, improved synchronisation between $\mathrm{N}$ application and plant demands, catch and cover crops (where applicable), spatially optimised precision fertilisation technologies (such as infrared spectroscopy), appropriate product storage (closed tanks), low $\mathrm{NH}_{3}$ emission application techniques (such as injection and immediate incorporation), and soil compaction prevention techniques (such as reduced tillage, low pressure tires, and drag hose systems). 


\section{Conclusions}

The study showed that $\mathrm{Cu}$ and $\mathrm{Zn}$ from co-digested manure mostly met the RENURE criteria: $5.3 \%$ of the 1035 considered cases were above the $800 \mathrm{mg} \mathrm{Zn} \mathrm{kg}^{-1} \mathrm{DM}$ limit; $5.0 \%$ of the 1038 available cases for $\mathrm{Cu}$ were above the $300 \mathrm{mg} \mathrm{Cu} \mathrm{kg}^{-1} \mathrm{DM}$ limit. Moreover, as $\mathrm{Cu}$ and $\mathrm{Zn}$ are essential co-factors in the plant's metabolic pathways, these numbers would suggest that digestate application would thus constitute an added benefit for crop growth in terms of $\mathrm{Cu}$ and $\mathrm{Zn}$ availability, rather than an environmental liability. When applying the $\mathrm{N}_{\min } / \mathrm{TN} \geq 90 \%$ criterion to the digestate database, just above $5 \%$ (96 of 1856 entries) met the condition; while $36 \%$ (574 out of 1583 entries) met the TOC/TN $\leq 3$ criterion. Thus, the $\mathrm{N}_{\min } / \mathrm{TN}$ criterion appeared more stringent than the TOC/TN criterion. As expected, targeting the LF of digestate led to a higher compliance rate, between 43 and $58 \%$ depending on DM range, indicating that LF is a better suited RENURE product than unseparated digestate. Our findings were consistent with those of the JRC's RENURE study regarding some separation technologies being more efficient than others in terms of solids' removal and/or $\mathrm{N}_{\min }$ upcycling, thus increasing the likelihood of these technologies to provide RENURE-compliant fertilisers.

Author Contributions: Conceptualization: G.R., E.M. (Erik Meers) and I.S.; Methodology: G.R.; Formal analysis: G.R.; Investigation: G.R.; Data curation: G.R.; Writing—original draft preparation: G.R.; Writing-review and editing: G.R., E.M. (Erik Meers), I.S. and H.D.; Supervision: E.M. (Erik Meers) and I.S.; Project administration: E.M. (Evi Michels); Funding acquisition: E.M. (Erik Meers) and H.D.; Resources: E.M. (Erik Meers) and H.D. All authors have read and agreed to the published version of the manuscript.

Funding: This research was funded by the European Union's Horizon 2020 Research and Innovation programme under project "NUTRI2CYCLE, Transition towards a more carbon and nutrient efficient agriculture in Europe, grant agreement No 773682".

Institutional Review Board Statement: Not applicable.

Informed Consent Statement: Not applicable.

Data Availability Statement: Data shared upon reasonable request (gregory.reuland@ugent.be).

Acknowledgments: EBA Industrial Chair. Franz Kirchmeyr, David Wilken, and Bernhard Stürmer for their invaluable role in the collection of data.

Conflicts of Interest: The authors declare no conflict of interest. The funders had no role in the design of the study; in the collection, analyses, or interpretation of data; in the writing of the manuscript; or in the decision to publish the results.

\section{Appendix A}

Table A1. $\mathrm{NH}_{4}-\mathrm{N}=$ ammonium nitrogen $\left(\mathrm{N}_{\min }\right) ; \mathrm{DM}=$ dry matter; $\mathrm{OM}=$ organic matter; $\mathrm{TOC}=$ total organic carbon; $\mathrm{TN}=$ total nitrogen; $\mathrm{K}_{2} \mathrm{O}=$ potassium oxide; $\mathrm{P}_{2} \mathrm{O}_{5}=$ phosphorus pentoxide; $\mathrm{Zn}=$ zinc; $\mathrm{Cu}=\operatorname{copper} ; \mathrm{n}=$ digestate sample size.

\begin{tabular}{ccccc}
\hline Parameter & Unit & Mean \pm Stdev & Median & $\mathbf{n}$ \\
\hline $\mathrm{DM}$ & $\mathrm{g} \mathrm{kg}^{-1} \mathrm{FM}$ & $55.96 \pm 31.57$ & 51 & 153 \\
$\mathrm{OM}$ & $\mathrm{g} \mathrm{kg}^{-1} \mathrm{DM}$ & $661.13 \pm 83.37$ & 684 & 47 \\
$\mathrm{TOC}$ & $\mathrm{g} \mathrm{kg}^{-1} \mathrm{DM}$ & $353.79 \pm 66.21$ & 369 & 68 \\
$\mathrm{pH}$ & - & $8.14 \pm 0.49$ & 8.2 & 87 \\
$\mathrm{TN}$ & $\mathrm{g} \mathrm{kg}^{-1} \mathrm{DM}$ & $85.48 \pm 47.59$ & 75.81 & 153 \\
$\mathrm{~N}_{\text {min }}\left(\mathrm{NH}_{4}-\mathrm{N}\right)$ & $\mathrm{g} \mathrm{kg}^{-1} \mathrm{DM}$ & $56.97 \pm 39.03$ & 459.6 & 137 \\
$\mathrm{~K}_{2} \mathrm{O}$ & $\mathrm{g} \mathrm{kg}^{-1} \mathrm{DM}$ & $57.98 \pm 33.17$ & 48.65 & 56 \\
$\mathrm{P}_{2} \mathrm{O}$ & $\mathrm{g} \mathrm{kg}^{-1} \mathrm{DM}$ & $37.72 \pm 27.53$ & 29.5 & 107 \\
$\mathrm{Zn}$ & $\mathrm{mg} \mathrm{kg}^{-1} \mathrm{DM}$ & $863.83 \pm 1039$ & 440 & 22 \\
$\mathrm{Cu}$ & $\mathrm{mg} \mathrm{kg}^{-1} \mathrm{DM}$ & $312.39 \pm 469.08$ & 137.55 & 22 \\
\hline
\end{tabular}


Table A2. $\mathrm{NH}_{4}-\mathrm{N}=$ ammonium nitrogen $\left(\mathrm{N}_{\min }\right) ; \mathrm{DM}=$ dry matter; $\mathrm{OM}=$ organic matter; $\mathrm{TOC}=$ total organic carbon; $\mathrm{TN}=$ total nitrogen; $\mathrm{K}_{2} \mathrm{O}=$ potassium oxide; $\mathrm{P}_{2} \mathrm{O}_{5}=$ phosphorus pentoxide; $\mathrm{Zn}$ = zinc; $\mathrm{Cu}=$ copper; $\mathrm{Hg}=$ mercury; $\mathrm{n}=$ digestate sample size.

\begin{tabular}{ccccc}
\hline Parameter & Unit & Mean \pm Stdev & Median & $\mathbf{n}$ \\
\hline $\mathrm{DM}$ & $\mathrm{g} \mathrm{kg}^{-1} \mathrm{FM}$ & $76.38 \pm 29.04$ & 82.15 & 14 \\
$\mathrm{OM}$ & $\mathrm{g} \mathrm{kg}^{-1} \mathrm{DM}$ & $628.66 \pm 128.11$ & 644.95 & 14 \\
$\mathrm{TOC}$ & $\mathrm{g} \mathrm{kg}^{-1} \mathrm{DM}$ & $267.75 \pm 46.90$ & 273.6 & 12 \\
$\mathrm{pH}$ & - & $8.09 \pm 0.80$ & 8.35 & 14 \\
$\mathrm{TN}$ & $\mathrm{g} \mathrm{kg}^{-1} \mathrm{DM}$ & $99.89 \pm 40.31$ & 85.6 & 14 \\
$\mathrm{~N}_{\min }\left(\mathrm{NH}_{4}-\mathrm{N}\right)$ & $\mathrm{g} \mathrm{kg}^{-1} \mathrm{DM}$ & $62.10 \pm 31.75$ & 50.4 & 14 \\
$\mathrm{~K}_{2} \mathrm{O}$ & $\mathrm{g} \mathrm{kg}^{-1} \mathrm{DM}$ & $76.70 \pm 54.53$ & 69.1 & 6 \\
$\mathrm{P}_{2} \mathrm{O}$ & $\mathrm{mg} \mathrm{kg}^{-1} \mathrm{DM}$ & $648.25 \pm 342.32$ & 63.95 & 6 \\
$\mathrm{Zn}$ & $\mathrm{mg} \mathrm{kg}^{-1} \mathrm{DM}$ & $170.17 \pm 168.26$ & 76.5 & 4 \\
$\mathrm{Cu}$ & $\mathrm{mg} \mathrm{kg}^{-1} \mathrm{DM}$ & $0.67 \pm 0.88$ & 0.67 & 6 \\
$\mathrm{Hg}$ & & & 2
\end{tabular}

Table A3. $\mathrm{NH}_{4}-\mathrm{N}=$ ammonium nitrogen $\left(\mathrm{N}_{\min }\right) ; \mathrm{DM}=$ dry matter; $\mathrm{OM}=$ organic matter; $\mathrm{TOC}=$ total organic carbon; $\mathrm{TN}=$ total nitrogen; $\mathrm{K}_{2} \mathrm{O}=$ potassium oxide; $\mathrm{P}_{2} \mathrm{O}_{5}=$ phosphorus pentoxide; $\mathrm{Zn}=$ zinc; $\mathrm{Cu}=$ copper; $\mathrm{Hg}=$ mercury; $\mathrm{n}=$ digestate sample size. Some of the datapoints were averages from several digestate samples, several biogas plants, and in some cases averages over several years; the added value of these entries is thus higher than what the ' $n$ ' datapoints let on.

\begin{tabular}{ccccc}
\hline Parameter & Unit & Mean \pm Stdev & Median & n \\
\hline $\mathrm{DM}$ & $\mathrm{g} \mathrm{kg}^{-1} \mathrm{FM}$ & $55.44 \pm 37.42$ & 50.9 & 22 \\
$\mathrm{OM}$ & $\mathrm{g} \mathrm{kg}^{-1} \mathrm{DM}$ & $645.32 \pm 93.79$ & 658.59 & 16 \\
$\mathrm{TOC}$ & $\mathrm{g} \mathrm{kg}^{-1} \mathrm{DM}$ & $332.91 \pm 127.57$ & 307.02 & 6 \\
$\mathrm{pH}$ & - & $8.02 \pm 0.38$ & 8.01 & 19 \\
$\mathrm{TN}$ & $\mathrm{g} \mathrm{kg}^{-1} \mathrm{DM}$ & $114.61 \pm 69.42$ & 98.5 & 11 \\
$\mathrm{~N}_{\mathrm{min}}\left(\mathrm{NH}_{4}-\mathrm{N}\right)$ & $\mathrm{g} \mathrm{kg}^{-1} \mathrm{DM}$ & $79.14 \pm 45.83$ & 45.83 & 18 \\
$\mathrm{~K}_{2} \mathrm{O}$ & $\mathrm{g} \mathrm{kg}^{-1} \mathrm{DM}$ & $61.27 \pm 29.35$ & 55.42 & 9 \\
$\mathrm{P}_{2} \mathrm{O}_{5}$ & $\mathrm{~g} \mathrm{~kg}^{-1} \mathrm{DM}$ & $45.81 \pm 36.73$ & 32.2 & 13 \\
$\mathrm{Zn}$ & $\mathrm{mg} \mathrm{kg}^{-1} \mathrm{DM}$ & $562.31 \pm 460.83$ & 423.55 & 11 \\
$\mathrm{Cu}$ & $\mathrm{mg} \mathrm{kg}^{-1} \mathrm{DM}$ & $107.39 \pm 62.15$ & 90 & 11 \\
$\mathrm{Hg}$ & $\mathrm{mg} \mathrm{kg}^{-1} \mathrm{DM}$ & $4.00 \times 10^{-2} \pm 4.50 \times 10^{-2}$ & $3.00 \times 10^{-2}$ & 6 \\
\hline
\end{tabular}

\section{References}

1. Amon, B.; Amon, T.; Boxberger, J.; Alt, C. Emissions of $\mathrm{NH}_{3}, \mathrm{~N}_{2} \mathrm{O}$ and $\mathrm{CH}_{4}$ from Dairy Cows Housed in a Farmyard Manure Tying Stall (Housing, Manure Storage, Manure Spreading). Nutr. Cycl. Agroecosyst. 2001, 60, 103-113. [CrossRef]

2. Petersen, S.O.; Sommer, S.G.; Béline, F.; Burton, C.; Dach, J.; Dourmad, J.Y.; Leip, A.; Misselbrook, T.; Nicholson, F.; Poulsen, H.D.; et al. Recycling of Livestock Manure in a Whole-Farm Perspective. Livest. Sci. 2007, 112, 180-191. [CrossRef]

3. Eurostat. Agri-Environmental Indicator-Greenhouse Gas Emissions-Statistics Explained. Available online: https://ec.europa. eu/eurostat/statistics-explained/index.php?title=Archive:Agri-environmental_indicator_-_greenhouse_gas_emissions (accessed on 17 May 2021).

4. Bouwman, L.; Goldewijk, K.K.; Van Der Hoek, K.W.; Beusen, A.H.W.; Van Vuuren, D.P.; Willems, J.; Rufino, M.C.; Stehfest, E. Erratum: Exploring Global Changes in Nitrogen and Phosphorus Cycles in Agriculture Induced by Livestock Production over the 1900-2050 Period. Proc. Natl. Acad. Sci. USA 2013, 110, 21196. [CrossRef] [PubMed]

5. Svanbäck, A.; McCrackin, M.L.; Swaney, D.P.; Linefur, H.; Gustafsson, B.G.; Howarth, R.W.; Humborg, C. Reducing Agricultural Nutrient Surpluses in a Large Catchment_Links to Livestock Density. Sci. Total Environ. 2019, 648, 1549-1559. [CrossRef]

6. European Commission. Report from the Commission to the Council and the European Parliament on the Implementation of Council Directive 91/676/EEC; European Commission: Brussels, Belgium, 2018; p. 14.

7. Koornneef, J.; Van Breevoort, P.; Noothout, P.; Hendriks, C.; Luning, L.; Camps, A. Global Potential for Biomethane Production with Carbon Capture, Transport and Storage up to 2050. Energy Procedia 2013, 37, 6043-6052. [CrossRef]

8. Brear, M.J.; Baldick, R.; Cronshaw, I.; Olofsson, M. Sector Coupling: Supporting Decarbonisation of the Global Energy System. Electr. J. 2020, 33, 106832. [CrossRef]

9. Gustafsson, M.; Svensson, N. Cleaner Heavy Transports-Environmental and Economic Analysis of Liquefied Natural Gas and Biomethane. J. Clean. Prod. 2021, 278, 123535. [CrossRef] 
10. Holm-Nielsen, J.B.; Al Seadi, T.; Oleskowicz-Popiel, P. The Future of Anaerobic Digestion and Biogas Utilization. Bioresour. Technol. 2009, 100, 5478-5484. [CrossRef]

11. Burg, V.; Bowman, G.; Haubensak, M.; Baier, U.; Thees, O. Valorization of an Untapped Resource: Energy and Greenhouse Gas Emissions Benefits of Converting Manure to Biogas through Anaerobic Digestion. Resour. Conserv. Recycl. 2018, 136, 53-62. [CrossRef]

12. Huygens, D.; Orveillon, G.; Lugato, E.; Tavazzi, S. Technical Proposals for the Safe Use of Processed Manure above the Threshold Established for Nitrate Vulnerable Zones by the Nitrates Directive (91/676/EEC); EUR 30363 EN; Publications Office of the European Union: Luxembourg, 2020. [CrossRef]

13. Hijbeek, R.H.F.M.; Whitmore, B.A.P.; ten Berge, H.F.M.; Whitmore, A.P.; Barkusky, D.; Schröder, J.J.; van Ittersum, M.K. Nitrogen Fertiliser Replacement Values for Organic Amendments Appear to Increase with N Application Rates. Nutr. Cycl. Agroecosyst. 2018, 110, 105-115. [CrossRef]

14. Sigurnjak, I.; Vaneeckhaute, C.; Michels, E.; Ryckaert, B.; Ghekiere, G.; Tack, F.M.G.; Meers, E. Fertilizer Performance of Liquid Fraction of Digestate as Synthetic Nitrogen Substitute in Silage Maize Cultivation for Three Consecutive Years. Sci. Total Environ. 2017, 599-600, 1885-1894. [CrossRef]

15. Möller, K.; Müller, T. Effects of Anaerobic Digestion on Digestate Nutrient Availability and Crop Growth: A Review. Eng. Life Sci. 2012, 12, 242-257. [CrossRef]

16. Monlau, F.; Sambusiti, C.; Ficara, E.; Aboulkas, A.; Barakat, A.; Carrère, H. New Opportunities for Agricultural Digestate Valorization: Current Situation and Perspectives. Energy Environ. Sci. 2015, 8, 2600-2621. [CrossRef]

17. Nkoa, R. Agricultural Benefits and Environmental Risks of Soil Fertilization with Anaerobic Digestates: A Review. Agron. Sustain. Dev. 2014, 34, 473-492. [CrossRef]

18. Vaneeckhaute, C.; Lebuf, V.; Michels, E.; Belia, E.; Vanrolleghem, P.A.; Tack, F.M.G.; Meers, E. Nutrient Recovery from Digestate: Systematic Technology Review and Product Classification. Waste Biomass Valorizat. 2017, 8, 21-40. [CrossRef]

19. Hjorth, M.; Christensen, K.V.; Christensen, M.L.; Sommer, S.G. Solid-Liquid Separation of Animal Slurry in Theory and Practice. Sustain. Agric. 2009, 2, 953-986. [CrossRef]

20. Romero-Güiza, M.S.; Mata-Alvarez, J.; María, J.; Rivera, C. Nutrient Recovery Technologies for Anaerobic Digestion Systems: An Overview Tecnologías de Recuperación de Nutrientes Para Los Sistemas de Digestión Anaeróbica: Revisión Tecnologias de Recuperação de Nutrientes Para Os Sistemas de Digestão Anaeróbia: R. Bucaramanga 2015, 29, 7-26.

21. Pognani, M.; D’Imporzano, G.; Scaglia, B.; Adani, F. Substituting Energy Crops with Organic Fraction of Municipal Solid Waste for Biogas Production at Farm Level: A Full-Scale Plant Study. Process Biochem. 2009, 44, 817-821. [CrossRef]

22. Cristina, G.; Camelin, E.; Pugliese, M.; Tommasi, T.; Fino, D. Evaluation of Anaerobic Digestates from Sewage Sludge as a Potential Solution for Improvement of Soil Fertility. Waste Manag. 2019, 99, 122-134. [CrossRef]

23. Tambone, F.; Orzi, V.; Zilio, M.; Adani, F. Measuring the Organic Amendment Properties of the Liquid Fraction of Digestate. Waste Manag. 2019, 88, 21-27. [CrossRef]

24. Voća, N.; Krička, T.; Ćosić, T.; Rupić, V.; Jukić, Ž.; Kalambura, S. Digested Residue as a Fertilizer after the Mesophilic Process of Anaerobic Digestion. Plant Soil Environ. 2005, 51, 262-266. [CrossRef]

25. Tambone, F.; Genevini, P.; D'Imporzano, G.; Adani, F. Assessing Amendment Properties of Digestate by Studying the Organic Matter Composition and the Degree of Biological Stability during the Anaerobic Digestion of the Organic Fraction of MSW. Bioresour. Technol. 2009, 100, 3140-3142. [CrossRef]

26. De la Fuente, C.; Alburquerque, J.A.; Clemente, R.; Bernal, M.P. Soil C and N Mineralisation and Agricultural Value of the Products of an Anaerobic Digestion System. Biol. Fertil. Soils 2013, 49, 313-322. [CrossRef]

27. Ernst, G.; Müller, A.; Göhler, H.; Emmerling, C. C and N Turnover of Fermented Residues from Biogas Plants in Soil in the Presence of Three Different Earthworm Species (Lumbricus terrestris, Aporrectodea longa, Aporrectodea caliginosa). Soil Biol. Biochem. 2008, 40, 1413-1420. [CrossRef]

28. Alburquerque, J.A.; de la Fuente, C.; Bernal, M.P. Chemical Properties of Anaerobic Digestates Affecting C and N Dynamics in Amended Soils. Agric. Ecosyst. Environ. 2012, 160, 15-22. [CrossRef]

29. Orzi, V.; Cadena, E.; Dimporzano, G.; Artola, A.; Davoli, E.; Crivelli, M.; Adani, F. Potential Odour Emission Measurement in Organic Fraction of Municipal Solid Waste during Anaerobic Digestion: Relationship with Process and Biological Stability Parameters. Bioresour. Technol. 2010, 101, 7330-7337. [CrossRef] [PubMed]

30. Tambone, F.; Scaglia, B.; D’Imporzano, G.; Schievano, A.; Orzi, V.; Salati, S.; Adani, F. Assessing Amendment and Fertilizing Properties of Digestates from Anaerobic Digestion through a Comparative Study with Digested Sludge and Compost. Chemosphere 2010, 81, 577-583. [CrossRef]

31. Vaneeckhaute, C.; Meers, E.; Michels, E.; Christiaens, P.; Tack, F.M.G. Fate of Macronutrients in Water Treatment of Digestate Using Vibrating Reversed Osmosis. Water. Air. Soil Pollut. 2012, 223, 1593-1603. [CrossRef]

32. Sigurnjak, I.; Michels, E.; Crappé, S.; Buysens, S.; Tack, F.M.G.; Meers, E. Utilization of Derivatives from Nutrient Recovery Processes as Alternatives for Fossil-Based Mineral Fertilizers in Commercial Greenhouse Production of Lactuca Sativa L. Sci. Hortic. Amst. 2016, 198, 267-276. [CrossRef]

33. Sigurnjak, I.; De Waele, J.; Michels, E.; Tack, F.M.; Meers, E.; De Neve, S. Nitrogen Release and Mineralization Potential of Derivatives from Nutrient Recovery Processes as Substitutes for Fossil Fuel-Based Nitrogen Fertilizers. Soil Use Manag. 2017, 33, 437-446. [CrossRef] 
34. Sigurnjak, I.; Michels, E.; Crappé, S.; Buysens, S.; Biswas, J.K.; Tack, F.M.G.; Neve, S.D.; Meers, E. Does Acidification Increase the Nitrogen Fertilizer Replacement Value of Bio-Based Fertilizers? J. Plant Nutr. Soil Sci. 2017, 180, 800-810. [CrossRef]

35. Vaneeckhaute, C.; Meers, E.; Michels, E.; Buysse, J.; Tack, F.M.G. Ecological and Economic Benefits of the Application of Bio-Based Mineral Fertilizers in Modern Agriculture. Biomass Bioenergy 2013, 49, 239-248. [CrossRef]

36. Vaneeckhaute, C.; Meers, E.; Michels, E.; Ghekiere, G.; Accoe, F.; Tack, F.M.G. Closing the Nutrient Cycle by Using Bio-Digestion Waste Derivatives as Synthetic Fertilizer Substitutes: A Field Experiment. Biomass Bioenergy 2013, 55, 175-189. [CrossRef]

37. Vaneeckhaute, C.; Janda, J.; Vanrolleghem, P.A.; Tack, F.M.G.; Meers, E. Phosphorus Use Efficiency of Bio-Based Fertilizers: Bioavailability and Fractionation. Pedosphere 2016, 26, 310-325. [CrossRef]

38. Chantigny, M.H.; Pelster, D.E.; Perron, M.-H.; Rochette, P.; Angers, D.A.; Parent, L.-É.; Massé, D.; Ziadi, N. Nitrous Oxide Emissions from Clayey Soils Amended with Paper Sludges and Biosolids of Separated Pig Slurry. J. Environ. Qual. 2013, 42, 30-39. [CrossRef] [PubMed]

39. De Boer, H.C. Co-Digestion of Animal Slurry Can Increase Short-Term Nitrogen Recovery by Crops. J. Environ. Qual. 2008, 37, 1968-1973. [CrossRef]

40. Abubaker, J.; Cederlund, H.; Arthurson, V.; Pell, M. Bacterial Community Structure and Microbial Activity in Different Soils Amended with Biogas Residues and Cattle Slurry. Appl. Soil Ecol. 2013, 72, 171-180. [CrossRef]

41. Alburquerque, J.A.; de la Fuente, C.; Campoy, M.; Carrasco, L.; Nájera, I.; Baixauli, C.; Caravaca, F.; Roldán, A.; Cegarra, J.; Bernal, M.P. Agricultural Use of Digestate for Horticultural Crop Production and Improvement of Soil Properties. Eur. J. Agron. 2012, 43, 119-128. [CrossRef]

42. Velthof, G.L.; Rietra, R.P.J.J. Nitrogen Use Efficiency and Gaseous Nitrogen Losses from the Concentrated Liquid Fraction of Pig Slurries. Int. J. Agron. 2019, 2019. [CrossRef]

43. Barłóg, P.; Hlisnikovský, L.; Kunzová, E. Effect of Digestate on Soil Organic Carbon and Plant-Available Nutrient Content Compared to Cattle Slurry and Mineral Fertilization. Agronomy 2020, 10, 379. [CrossRef]

44. Baral, K.R.; Labouriau, R.; Olesen, J.E.; Petersen, S.O. Nitrous Oxide Emissions and Nitrogen Use Efficiency of Manure and Digestates Applied to Spring Barley. Agric. Ecosyst. Environ. 2017, 239, 188-198. [CrossRef]

45. Müller-Stöver, D.S.; Sun, G.; Kroff, P.; Thomsen, S.T.; Hauggaard-Nielsen, H. Anaerobic Co-Digestion of Perennials: Methane Potential and Digestate Nitrogen Fertilizer Value. J. Plant Nutr. Soil Sci. 2016, 179, 696-704. [CrossRef]

46. Fouda, S.; Von Tucher, S.; Lichti, F.; Schmidhalter, U. Nitrogen Availability of Various Biogas Residues Applied to Ryegrass. J. Plant Nutr. Soil Sci. 2013, 176, 572-584. [CrossRef]

47. Cavalli, D.; Cabassi, G.; Borrelli, L.; Fuccella, R.; Degano, L.; Bechini, L.; Marino, P. Nitrogen Fertiliser Value of Digested Dairy Cow Slurry, Its Liquid and Solid Fractions, and of Dairy Cow Slurry. Ital. J. Agron. 2014, 9, 71-78. [CrossRef]

48. Bhogal, A.; Nicholson, F.A.; Rollett, A.; Taylor, M.; Litterick, A.; Whittingham, M.J.; Williams, J.R. Improvements in the Quality of Agricultural Soils Following Organic Material Additions Depend on Both the Quantity and Quality of the Materials Applied. Front. Sustain. Food Syst. 2018, 2, 1-13. [CrossRef]

49. Crolla, A.; Kinsley, C.; Pattey, E. Land Application of Digestate. Biogas Handb. Sci. Prod. Appl. 2013, 302-325. [CrossRef]

50. Gagnon, B.; Ziadi, N.; Chantigny, M.H.; Bélanger, G.; Massé, D.I. Biosolids from Treated Swine Manure and Papermill Residues Affect Corn Fertilizer Value. Agron. J. 2012, 104, 483-492. [CrossRef]

51. Riva, C.; Orzi, V.; Carozzi, M.; Acutis, M.; Boccasile, G.; Lonati, S.; Tambone, F.; D’Imporzano, G.; Adani, F. Short-Term Experiments in Using Digestate Products as Substitutes for Mineral (N) Fertilizer: Agronomic Performance, Odours, and Ammonia Emission Impacts. Sci. Total Environ. 2016, 547, 206-214. [CrossRef] [PubMed]

52. Sánchez-Rodríguez, A.R.; Carswell, A.M.; Shaw, R.; Hunt, J.; Saunders, K.; Cotton, J.; Chadwick, D.R.; Jones, D.L.; Misselbrook, T.H. Advanced Processing of Food Waste Based Digestate for Mitigating Nitrogen Losses in a Winter Wheat Crop. Front. Sustain. Food Syst. 2018, 2, 1-14. [CrossRef]

53. Tambone, F.; Adani, F. Nitrogen Mineralization from Digestate in Comparison to Sewage Sludge, Compost and Urea in a Laboratory Incubated Soil Experiment. Z. Pflanzenernahr. Bodenkd. 2017, 180, 355-365. [CrossRef]

54. Tambone, F.; Orzi, V.; D’Imporzano, G.; Adani, F. Solid and Liquid Fractionation of Digestate: Mass Balance, Chemical Characterization, and Agronomic and Environmental Value. Bioresour. Technol. 2017, 243, 1251-1256. [CrossRef] [PubMed]

55. Thomas, B.W.; Li, X.; Nelson, V.; Hao, X. Anaerobically Digested Cattle Manure Supplied More Nitrogen with Less Phosphorus Accumulation than Undigested Manure. Agron. J. 2017, 109, 836-844. [CrossRef]

56. Šimon, T.; Kunzová, E.; Friedlová, M. The Effect of Digestate, Cattle Slurry and Mineral Fertilization on the Winter Wheat Yield and Soil Quality Parameters. Plant Soil Environ. 2015, 62, 522-527. [CrossRef]

57. Walsh, J.J.; Jones, D.L.; Chadwick, D.R.; Williams, A.P. Repeated Application of Anaerobic Digestate, Undigested Cattle Slurry and Inorganic Fertilizer N: Impacts on Pasture Yield and Quality. Grass Forage Sci. 2018, 73, 758-763. [CrossRef]

58. Walsh, J.J.; Jones, D.L.; Edwards-Jones, G.; Williams, A.P. Replacing Inorganic Fertilizer with Anaerobic Digestate May Maintain Agricultural Productivity at Less Environmental Cost. J. Plant Nutr. Soil Sci. 2012, 175, 840-845. [CrossRef]

59. Bauer, A.; Mayr, H.; Hopfner-Sixt, K.; Amon, T. Detailed Monitoring of Two Biogas Plants and Mechanical Solid-Liquid Separation of Fermentation Residues. J. Biotechnol. 2009, 142, 56-63. [CrossRef]

60. Risberg, K.; Cederlund, H.; Pell, M.; Arthurson, V.; Schnürer, A. Comparative Characterization of Digestate versus Pig Slurry and Cow Manure-Chemical Composition and Effects on Soil Microbial Activity. Waste Manag. 2017, 61, 529-538. [CrossRef] [PubMed] 
61. Cavalli, D.; Corti, M.; Baronchelli, D.; Bechini, L.; Marino Gallina, P. CO2 Emissions and Mineral Nitrogen Dynamics Following Application to Soil of Undigested Liquid Cattle Manure and Digestates. Geoderma 2017, 308, 26-35. [CrossRef]

62. Xu, Y.; Yu, W.; Ma, Q.; Zhou, H. Accumulation of Copper and Zinc in Soil and Plant within Ten-Year Application of Different Pig Manure Rates. Plant Soil Environ. 2013, 59, 492-499. [CrossRef]

63. Zhang, Y.; Luo, W.; Jia, J.; Kong, P.; Tong, X.; Lu, Y.; Xie, L.; Ma, F.; Giesy, J.P. Effects of Pig Manure Containing Copper and Zinc on Microbial Community Assessed via Phospholipids in Soils. Environ. Monit. Assess. 2014, 186, 5297-5306. [CrossRef]

64. Foged, H.L.; Flotats, X.; Blasi, A.B.; Palatsi, J.; Magri, A.; Schelde, K.M. Inventory of Manure Processing Activities in Europe; Technical Report No. I to the European Commission, Directorate-General Environment, Manure Processing Activities in Europe; European Commission: Brussels, Belgium, 2011; p. 138.

65. Scarlat, N.; Fahl, F.; Dallemand, J.F.; Monforti, F.; Motola, V. A Spatial Analysis of Biogas Potential from Manure in Europe. Renew. Sustain. Energy Rev. 2018, 94, 915-930. [CrossRef]

66. Meyer, A.K.P.; Ehimen, E.A.; Holm-Nielsen, J.B. Future European Biogas: Animal Manure, Straw and Grass Potentials for a Sustainable European Biogas Production. Biomass Bioenergy 2018, 111, 154-164. [CrossRef]

67. Corden, C.; Bougas, K.; Cunningham, E.; Tyrer, D.; Kreißig, J.; Zetti, E.; Gamero, E.; Wildey, R.; Crookes, M. Digestate and Compost as Fertilisers: Risk Assessment and Risk Management Options; Wood Environment \& Infrastructure Solutions UK Ltd.: Cheshire, UK, 2019.

68. Metson, G.S.; Feiz, R.; Quttineh, N.-H.; Tonderski, K. Optimizing Transport to Maximize Nutrient Recycling and Green Energy Recovery. Resour. Conserv. Recycl. 2021, X, 100049. [CrossRef]

69. Eurostat. Consumption of Inorganic Fertilizers, AEI_FM_USEFERT. Available online: https://ec.europa.eu/eurostat/ databrowser/view/aei_fm_usefert/default/table?lang=en (accessed on 17 May 2021).

70. Zilio, M.; Pigoli, A.; Rizzi, B.; Geromel, G.; Meers, E.; Schoumans, O.; Giordano, A.; Adani, F. Measuring Ammonia and Odours Emissions during Full Field Digestate Use in Agriculture. Sci. Total Environ. 2021, 782, 146882. [CrossRef] [PubMed]

71. Möller, K. Effects of Anaerobic Digestion on Soil Carbon and Nitrogen Turnover, N Emissions, and Soil Biological Activity. A Review. Agron. Sustain. Dev. 2015, 35, 1021-1041. [CrossRef]

72. Sager, M. Trace and Nutrient Elements in Manure, Dung and Compost Samples in Austria. Soil Biol. Biochem. 2007, 39, 1383-1390. [CrossRef]

73. Brown, P.H.; Cakmak, I.; Zhang, Q. Form and Function of Zinc Plants. Zinc Soils Plants 1993, 93-106. [CrossRef]

74. Nordlander, B.; Krantz, M.; Hohmann, S. Hog1-Mediated Metabolic Adjustments Following Hyperosmotic Shock in the Yeast. Current 2008, 20. [CrossRef]

75. Tsachidou, B.; Scheuren, M.; Gennen, J.; Debbaut, V.; Toussaint, B.; Hissler, C.; George, I.; Delfosse, P. Biogas Residues in Substitution for Chemical Fertilizers: A Comparative Study on a Grassland in the Walloon Region. Sci. Total Environ. 2019, 666, 212-225. [CrossRef]

76. Insam, H.; Gómez-Brandón, M.; Ascher, J. Manure-Based Biogas Fermentation Residues—Friend or Foe of Soil Fertility? Soil Biol. Biochem. 2015, 84, 1-14. [CrossRef]

77. Barbosa, D.B.P.; Nabel, M.; Jablonowski, N.D. Biogas-Digestate as Nutrient Source for Biomass Production of Sida Hermaphrodita, Zea Mays L. and Medicago Sativa L. Energy Procedia 2014, 59, 120-126. [CrossRef]

78. Gunnarsson, A.; Bengtsson, F.; Caspersen, S. Use Efficiency of Nitrogen from Biodigested Plant Material by Ryegrass. J. Plant Nutr. Soil Sci. 2010, 173, 113-119. [CrossRef]

79. Nicholson, F.A.; Bhogal, A.; Rollett, A.; Taylor, M.; Williams, J.R. Precision Application Techniques Reduce Ammonia Emissions Following Food-Based Digestate Applications to Grassland. Nutr. Cycl. Agroecosyst. 2018, 110, 151-159. [CrossRef]

80. Nicoletto, C.; Costa, L.D.; Sambo, P.; Zanin, G. Distillery Anaerobic Digestion Residues as Fertilizers for Field Vegetable Crops: Performance and Efficiency in Mid-Term Successions. Agronomy 2019, 9, 463. [CrossRef]

81. Riau, V.; Burgos, L.; Camps, F.; Domingo, F.; Torrellas, M.; Antón, A.; Bonmatí, A. Closing Nutrient Loops in a Maize Rotation. Catch Crops to Reduce Nutrient Leaching and Increase Biogas Production by Anaerobic Co-Digestion with Dairy Manure. Waste Manag. 2021, 126, 719-727. [CrossRef] [PubMed]

82. Valentinuzzi, F.; Cavani, L.; Porfido, C.; Terzano, R.; Pii, Y.; Cesco, S.; Marzadori, C.; Mimmo, T. The Fertilising Potential of Manure-Based Biogas Fermentation Residues: Pelleted vs. Liquid Digestate. Heliyon 2020, 6. [CrossRef] [PubMed]

83. European Commission. Task 2.11 Study on the Behaviour of Digestate in Agricultural Soils: "Providing Support in Relation to the Implementation of the Nitrates Directive (91/676/EEC)"; European Commission: Brussels, Belgium, 2014; pp. 1-28, No. 07.

84. Wang, L.L.; Li, W.Z.; Wang, Z.J.; Wang, Z.W.; Sui, C.; Li, Y. Effects of Digestate Application Depth on Soil Nitrogen Volatilization and Vertical Distribution. Int. J. Agric. Biol. Eng. 2016, 9, 101-107. [CrossRef]

85. Verdi, L.; Mancini, M.; Ljubojevic, M.; Orlandini, S.; Marta, A.D. Greenhouse Gas and Ammonia Emissions from Soil: The Effect of Organic Matter and Fertilisation Method. Ital. J. Agron. 2018, 13, 260-266. [CrossRef]

86. Badagliacca, G.; Petrovičovà, B.; Pathan, S.I.; Roccotelli, A.; Romeo, M.; Monti, M.; Gelsomino, A. Use of Solid Anaerobic Digestate and No-Tillage Practice for Restoring the Fertility Status of Two Mediterranean Orchard Soils with Contrasting Properties. Agric. Ecosyst. Environ. 2020, 300. [CrossRef] 